NBER WORKING PAPER SERIES

\title{
GLOBAL HOUSE PRICE FLUCTUATIONS: SYNCHRONIZATION AND DETERMINANTS
}

\author{
Hideaki Hirata \\ M. Ayhan Kose \\ Christopher Otrok \\ Marco E. Terrones \\ Working Paper 18362 \\ http://www.nber.org/papers/w18362 \\ NATIONAL BUREAU OF ECONOMIC RESEARCH \\ 1050 Massachusetts Avenue \\ Cambridge, MA 02138 \\ September 2012
}

We thank our discussants, Kirstin Hubrich and Leonardo Melosi, for their very useful suggestions. We are grateful for helpful comments from Stijn Claessens, Michael Fratantoni, Massimo Guidolin, Fabrizio Perri, Helen Rey, Barbara Rossi, Lars Svensson, Kenneth West, and participants at the 2012 NBER-ISOM Conference in Oslo, and at seminars at Indiana University, Purdue University and Emory University. An earlier version of this paper was circulated under the title "House Prices, Interest Rates and Macroeconomic Fluctuations: International Evidence." We thank Ezgi Ozturk for providing outstanding research assistance. The views expressed in this paper are those of the authors and do not necessarily represent those of the IMF or Federal Reserve Bank of St Louis. The views expressed herein are those of the authors and do not necessarily reflect the views of the National Bureau of Economic Research.

NBER working papers are circulated for discussion and comment purposes. They have not been peerreviewed or been subject to the review by the NBER Board of Directors that accompanies official NBER publications.

(C) 2012 by Hideaki Hirata, M. Ayhan Kose, Christopher Otrok, and Marco E. Terrones. All rights reserved. Short sections of text, not to exceed two paragraphs, may be quoted without explicit permission provided that full credit, including $(\mathrm{C}$ notice, is given to the source. 
Global House Price Fluctuations: Synchronization and Determinants

Hideaki Hirata, M. Ayhan Kose, Christopher Otrok, and Marco E. Terrones

NBER Working Paper No. 18362

September 2012

JEL No. E32,E43,E52,G15,R31

\begin{abstract}
We examine the properties of house price fluctuations across eighteen advanced economies over the past forty years. We ask two specific questions: First, how synchronized are housing cycles across these countries? Second, what are the main shocks driving movements in global house prices? To address these questions, we first estimate the global components in house prices and various macroeconomic and financial variables. We then evaluate the roles played by a variety of global shocks, including shocks to interest rates, monetary policy, productivity, credit, and uncertainty, in explaining house price fluctuations using a wide range of FAVAR models. We find that house prices are synchronized across countries, and the degree of synchronization has increased over time. Global interest rate shocks tend to have a significant negative effect on global house prices whereas global monetary policy shocks per se do not appear to have a sizeable impact. Interestingly, uncertainty shocks seem to be important in explaining fluctuations in global house prices.
\end{abstract}

Hideaki Hirata

Faculty of Business Administration

Hosei University

Japan

h-hirata@i.hosei.ac.jp

M. Ayhan Kose

Research Department

International Monetary Fund

700 19th Street, N.W.

Washington, DC 20431

akose@imf.org
Christopher Otrok

Department of Economics

University of Missouri

Columbia, MO 65211

and Federal Reserve Bank of St Louis

otrokc@missouri.edu

Marco E. Terrones

Research Department

International Monetary Fund

700 19th Street, N.W.

Washington DC 20431

mterrones@imf.org 


\section{Introduction}

House prices in many advanced countries have moved in tandem during the past decade. They first increased unusually rapidly prior to the global financial crisis reaching in some cases levels not previously seen. House prices then collapsed over the period 2006-11 and have recently started to rebound in some of these countries. These highly synchronized fluctuations in housing markets first coincided with a period of high growth, but then were followed by severe financial disruptions and deep recessions. In light of these observations, this paper addresses two specific questions to have a better understanding of fluctuations in global housing markets: First, how synchronized are housing cycles across countries? Second, what are the main shocks driving movements in global house prices?

Our interest in house prices is clearly motivated by recent developments, but there are also simpler, and probably more fundamental, reasons to study the dynamics of housing markets because of the key role housing plays in modern societies. First, housing satisfies peoples' need for shelter. Second, housing related activities account for an important fraction of GDP and household expenditures. Third, housing is the main asset and mortgage debt is the main liability held by households in many advanced countries. Therefore, large movements in house prices, by affecting households' net wealth and their capacity to borrow and spend in residential investment, can have serious macroeconomic implications.

In theory, interactions between house prices and the real economy can be amplified when financial imperfections are present. This amplification largely occurs through the financial accelerator and related mechanisms operating through firms, households and countries' balance sheets. According to these mechanisms, an increase (decrease) in asset prices improves (worsens) an entity's net worth, enhancing (reducing) its capacity to borrow, invest, and consume. This process, in turn, can lead to further increases (decreases) in house prices and produce general equilibrium effects. ${ }^{1}$ In other words, disturbances in housing markets can translate into much larger cyclical fluctuations in the real economy.

A number of recent theoretical studies have shown how developments in housing markets can magnify and transmit shocks to the real economy using the financial accelerator mechanism in the context of DSGE models. For example, Iacoviello (2005) constructs a model with firms' collateral constraints connected to real estate, and finds that collateral effects are critical to replicate the changes in consumption in response to movements in house prices. ${ }^{2}$ Other studies have focused on how credit constraints affect macroeconomic fluctuations using a framework where house prices and business investment are linked (Liu, Wang, and Zha, 2011).

\footnotetext{
${ }^{1}$ Early contributions include Bernanke and Gertler (1989), Bernanke, Gertler, and Gilchrist (1999), and Kiyotaki and Moore (1997). Surveys of this literature can be found in Gertler (1988) and Claessens, Kose, and Terrones (2012).

2 Aoki, Proudman and Vlieghe (2004) quantify the effect of shocks on housing investment, house prices and consumption in a model in which houses serve as collateral to reduce agency costs related to borrowing. Other studies analyze the importance of disturbances in housing markets in explaining certain features of business cycles (see Monacelli (2009) and Davis and Heathcote (2005)).
} 
A series of recent empirical studies document strong linkages between developments in housing markets and the real economy. For example, Claessens, Kose, and Terrones $(2010,2012)$ report that downturns in housing markets are highly synchronized across countries and that the degree of comovement rises especially during periods of synchronized recessions (Figure 1). Their results suggest that recessions accompanied with housing busts tend to be longer and deeper than other recessions, and recoveries associated with housing booms are often shorter and stronger (Table 1). ${ }^{3}$

Despite the apparent consensus on the importance of housing market movements for the real economy, our understanding of the sources of synchronization in housing markets is rather limited. As we summarize in the next section, a number of studies analyze the sources of house price movements, but they report mixed findings. Moreover, the nature and identification of shocks vary significantly across studies making the interpretation of their findings difficult. For instance, some studies emphasize the importance of country-specific house price shocks in the transmission and synchronization of house prices. Others argue that interest rate shocks play a key role in driving movements in house prices. There are also other studies highlighting the importance of demand and supply shocks in housing markets and country-specific structural characteristics.

Our study contributes to the large body of research by focusing on the extent and sources of the synchronization in global housing cycles. Specifically, we extend the literature in four dimensions. First, we study different measures of the synchronization of house prices and analyze how the features of house price cycles compare with cycles in output and other financial variables. Second, we identify shocks driving house prices using various approaches commonly employed in the literature, including a standard recursive method and one based on sign restrictions. In the former, we consider how shocks to output, house prices, equity prices, credit, and interest rates affect movements in house prices. In the latter, we formally identify and study the importance of a sequence of structural shocks, including monetary, credit, productivity, and uncertainty shocks.

Third, we employ a series of FAVAR (Factor Augmented VAR) models to analyze the importance of different types of shocks in explaining movements in global house prices. It is critical to study how house prices react to worldwide shocks to get a better understanding of the synchronization of global housing cycles. Finally, we consider the impact of shocks on housing cycles in different groups of advanced countries over a long period.

The remainder of this paper is organized as follows. In Section II, we briefly summarize recent research analyzing the roles of different types of shocks in explaining house price movements. In Section III, we introduce our database and methodology. In Section IV, we present the main features of housing cycles and analyze the synchronization of housing cycles. In Section V, we analyze the

\footnotetext{
${ }^{3}$ Leamer (2007) documents that there are strong linkages between cycles in housing markets and business cycles in the United States. There is evidence that the duration and amplitude of housing cycles vary widely across geographical areas and through time (Cunningham and Kolet, 2007; Hall, McDermott and Tremewan, 2006). Alvarez and others (2010) report that regional housing markets are weakly correlated in the major euro area countries. This reflects variations in demand-supply conditions, characteristics of housing finance, and linkages between housing and real activity.
} 
importance of a variety of shocks in driving house prices. Section VI concludes.

\section{What Do We Know About Synchronization of House Prices? A Brief Review}

There is a growing literature that analyzes the importance of various shocks in driving national and global house prices. We present a brief review of this literature considering three types of studies according to the methods they employed. As the review shows, the literature paints a rather blurry picture about the relative importance of different types of shocks.

Studies employing VAR models. The first group of studies examines the roles played by shocks to interest rates or monetary policy in explaining national house prices using VAR models. Some of these studies use a recursive scheme to identify shocks (Assenmacher-Wesche and Gerlach, 2010; Calza and others, 2009; Goodhart and Hoffmann, 2008; Cardarelli and others, 2008; Gupta and others, 2012). In these studies, shocks to interest rates are often interpreted as monetary policy shocks. Others employ sign restrictions to identify monetary policy shocks (Carstensen et. al, 2009; Del Negro and Otrok, 2007; Jarocinski and Smets, 2008). Some recent studies also consider the importance of the housing sector in the transmission of monetary policy (see Feroli and others, 2012). Sa, Towbin, and Wieladek (2011) find that house prices respond more to monetary policy shocks in countries with more developed mortgage markets using a VAR model. In his survey of this growing literature, Kuttner (2012) concludes that the evidence suggests "the impact of interest rates on house prices appears to be quite modest." In particular, he notes that the estimated impact of interest rates shocks on house prices reported in these studies are consistently smaller than the predictions of the standard user cost theory of house prices.

Studies employing Global VAR (GVAR) models. Studies in the second group mostly use GVAR models to analyze the transmission and synchronization of house prices across countries. Ambrogio CesaBianchi (2011), for instance, report that house price shocks originating in the United States play a significant role in driving global house prices. In contrast, Hiebert and Vansteenkiste (2009) conclude that house price shocks play a relatively minor role in explaining house price spillovers in the euro area. Vansteenkiste (2007) consider the same approach in the context of the US states and find that house price shocks in California appear to be an important factor driving prices in other states. The GVAR methodology does not structurally identify shocks implying that there is no economic interpretation of the housing shocks in these studies. In addition, since the methodology characterizes cross-border linkages by averaging variables into a global aggregate, it is difficult to understand how country weights affect the influence of individual country variables in the transmission of shocks across borders.

Studies considering a wider range of shocks and methods. The third group of studies includes research that employs various other methodologies, including dynamic factor and FAVAR models. These also provide mixed results about the importance of different types of shocks in explaining housing cycles. For example, Case, Goetzmann and Rouwenhorst (1999), who study the dynamics of international commercial real estate markets from 1987-1997 using global factors, report that the comovement among commercial real estate markets is through output linkages. Terrones and Otrok (2004) examine the synchronization of housing prices in a sample of 14 advanced countries using a FAVAR model from 1970-2004. They find evidence of a global housing cycle, which moves closely with global GDP but they do not identify the sources of the changes in house prices. In a related study, de Bandt, 
Barhoumi and Bruneau (2010) find that house prices in the United States lead movements in house prices in other OECD countries using a FAVAR model. Beltratti and Morana (2010) also consider a FAVAR model using the G-7 countries. They identify shocks using a recursive decomposition and consider demand, supply, house price, stock price, and oil price shocks. They report that both house price and supply shocks are important in explaining global house price movements. ${ }^{4}$

\section{Database and Methodology}

\section{III.1. Database}

Our main dataset includes quarterly series of GDP, house prices, equity prices, credit, and the shortand long-term interest rates of 18 advanced OECD countries for the period 1971:1-2011:3. We concentrate on this sample because it provides a broad perspective of fluctuations in global housing markets and it is a common denominator of the cross-country data we analyze. Our sample provides a good representation of developments in global housing markets as it accounts for slightly more than 60 percent of global GDP over the 1971-2011 period (in PPP exchange rates).

We provide a systematic examination of the synchronization of house prices and the sources of this synchronization over two different sub-periods. The first sub-period, 1971:1-84:4, witnessed a set of common shocks associated with sharp fluctuations in the price of oil and contractionary monetary policy in major industrial economies. We call this period the "pre-globalization period." The second period, 1985:1-2011:3, represents the "globalization period" in which there were dramatic increases in the volume of cross-border trade in both goods and assets. This period also covers a substantial portion of the so-called "Great Moderation" era as well as the latest global financial crisis, and coincides with a rapid increase in trade and financial linkages among the advanced countries and a broader converge of their business cycles (see Kose, Otrok, and Whiteman, 2008). This demarcation is helpful for differentiating the impact of common shocks from that of globalization on the degree of comovement of housing cycles.

House prices correspond to various measures of indices of house or land prices depending on the source country. ${ }^{5}$ Equity prices are share price indices weighted with market value of outstanding shares. Our measure of credit is aggregate claims on the private sector by deposit money banks. This measure is also used in earlier cross-country studies on credit dynamics (Mendoza and Terrones, 2008; and Claessens, Kose, and Terrones, 2010). We track aggregate business cycles with real GDP measured by chained volume series. The short-term interest rates correspond to nominal short-term

\footnotetext{
${ }^{4}$ Igan and Loungani (2009) document that long-run house price dynamics in advanced countries are mostly driven by local fundamentals such as demographics and construction costs, though market structure and regulatory factors may cause short-run fluctuations.

${ }^{5}$ It would be useful to include a measure of house volumes in addition to house prices (Moench and Ng, 2010; Stock and Watson, 2009). However, such a measure is not available for the large cross-country sample we are exploring here. House price series are also subject to various problems given that different countries use different concepts to keep track of price movements in housing markets (Silver, 2012).
} 
government bill rates, generally the Treasury Bill Rates, and the long-term interest rates typically are those of the long-term government bonds.

We also use measures of uncertainty, reserves, credit spreads and default rates. Following Bloom (2009), uncertainty is constructed using the volatility of daily equity prices of the G-7 countries. ${ }^{6}$ Reserves series correspond to total reserves. Unlike other variables, credit spread and default rates series are available for only the United States. In order to measure credit spreads, we use corporate bond spreads which are the yield differences between Moody's Seasoned Aaa and Baa corporate bonds for the U.S. The Aaa bonds are "judged to be the highest quality with minimal credit" risk while the Baa bonds are "subject to moderate credit risk and possess certain speculative characteristics". 7 The default rate series corresponds to the monthly rates for Moody's rated U.S. speculative-grade corporate bonds. As in the case of credit spreads, we take the observation of the last month of each quarter as our quarterly default rates.

Before constructing our factors and estimating the VAR models, we make appropriate transformations in each data series. Whenever necessary, we deflate the series using the CPI to obtain real variables. We take four-quarter growth rates of house prices, credit, equity prices, and GDP. All variables are seasonally adjusted and expressed in percentages. We provide a detailed list of the data series and their sources in Appendix I.

\section{III.2. Methodology}

Since our objective is to analyze the extent and sources of synchronization of house price fluctuations, we undertake our exercise in three steps. First, we study the main features of house price movements by paying special attention to the extent of their synchronization. For this purpose, we use a range of approaches, including basic correlations and concordance statistics. Second, we estimate the common component (global factor) in each variable. Third, we use a set of FAVAR models to analyze the importance of various shocks that could explain fluctuations in house prices. We briefly explain next the estimation of global factors and FAVAR models.

Estimation of Global Factors. To estimate the global factors, we extract the first principal component of each variable in our database. There are, of course, alternative approaches to construct global equivalents of these variables. For example, we could employ a full-fledged dynamic factor model, as in Kose, Otrok, and Whiteman (2003). Their method is particularly useful to simultaneously estimate different common factors, such as the global, regional, and country-specific factors. However, the

\footnotetext{
${ }^{6}$ Some other measures of uncertainty, including policy uncertainty, have recently been introduced. However, their coverage are not comprehensive enough for our purposes here (Bloom, 2009; Baker, Bloom, and Davis, 2012).

${ }^{7}$ Since there is no single accepted measure of credit spreads, the recent literature on the importance of credit shocks employs various alternative ones. For instance, Meeks (2012) uses a measure of credit spreads defined in terms of a risky bond portfolio that belongs to Moody's B1/B2 category. Such a portfolio is described by Moody's as being subject to "high credit risk". Gilchrist, Yankov and Zakrajsek (2009) take a panel of credit spreads and estimate a common factor of these spreads as their measure.
} 
global factor obtained with a dynamic factor model is quite similar to the first principal component. We use the simpler approach here since we are only interested in the global component of each variable.

Figure 2 presents some of the estimated global factors. The estimated factors are broadly consistent with a number of well-known cyclical episodes in the global economy. For instance, the downturns in the estimated global house price factor take place around the global recessions. The downturn during the latest episode is particularly striking because of its highly synchronous nature and its depth. The increase in the global housing factor in the mid-1980s was larger than that prior to the recent financial crisis because a larger number of countries experienced greater growth in house prices over a short time period in the former episode. In contrast, global house prices grew gradually over a long period before the financial crisis. The global factor has recently started picking up because of the growth of house prices in some countries, including Australia, Canada, Switzerland, and some Nordic nations. The global output factor is able to capture the growth dynamics around global recessions and recoveries. The estimated factors of other financial variables also reveal interesting patterns as they register significant declines prior to or during the periods of global recessions. The global credit factor features contractions during periods of downturns in housing markets illustrating the strong interactions between credit and housing markets.

FAVAR Models. The FAVAR models we estimate can be represented by:

$$
\begin{gathered}
\mathrm{y}_{\mathrm{t}}=\mathrm{a}_{(0)}+\mathrm{A}_{(1)} \mathrm{y}_{(\mathrm{t}-1)}+\mathrm{A}_{(2)} \mathrm{y}_{\mathrm{t}-2}+\ldots+\mathrm{A}_{(\mathrm{l})} \mathrm{y}_{\mathrm{t}-\mathrm{l}}+\mathrm{u}_{\mathrm{t}} \\
\mathrm{t}=1, \ldots, \mathrm{T} \text {, and } \mathrm{l}=1, \ldots, \mathrm{L}
\end{gathered}
$$

where $y_{t}$ is an $m \times 1$ vector of variables at date $t, A_{l}$ is an $m \times m$ coefficient matrix for each lag of the variable vector with $a_{(0)}$ being the constant term, and $m$ is the number of variables in the model. $u_{t}$ is the vector of one-step ahead prediction error. We consider two types of FAVAR models, which differ only in terms of the set of variables in the $y_{t}$ vector. The first type contains only the estimated global factors. The second type mostly includes a mix of the estimated global factors and some country specific variables, such as default rate, and spreads. ${ }^{8}$ In our estimation, the lag length, $l$, is kept at four. When we use sign restrictions to identify the shocks, we employ Bayesian methods to estimate the models. We use a symmetric (across variables) prior with a harmonic decay. ${ }^{9}$ We present a discussion of the identification of shocks and the use of these models in section $\mathrm{V}$.

\footnotetext{
${ }^{8}$ The model follows the work of Bernanke, Boivin, and Eliasz (2005) who developed the FAVAR model to study the effects of monetary policy in a closed economy framework. They compare FAVARs that treat estimated factors as data as is done here, with more sophisticated Bayesian estimates that account for uncertainty in the estimated factors. They conclude that there is no real gain from the more computationally intensive Bayesian methods for this type of problem. It would be useful to consider a model explicitly accounting nonlinearities to analyze the impact of shocks on house prices during periods of high and low financial stress episodes (Hubrich and Tetlow, 2011).

${ }^{9}$ We estimated our FAVAR models using RATS. The tightness parameter is 0.2 . We experimented with a tightness of 0.1 and 0.5 and found the results to be unchanged other than small differences in the coverage intervals.
} 
As it is often the case in the VAR literature, we need to make challenging decisions with respect to our modeling choices. Ideally, we would use the same set of variables in each model. However, this would require a grand model to nest all the different specifications we have because identification of each shock with sign restrictions requires different data series. One approach to address this, for instance, could be to estimate a large model and then be aggressive on using priors as shrinkage (as is done in the forecasting literature). However, this could lead to problems in identifying some of the shocks, if one pushes the coefficients on some of the variables towards zero which may be needed for the identification of one shock but not another. Instead, we include as many of the same variables as possible across our models but we note that each model contains a few time series not present in the other models. We do not consider a formal lag length test in each model, but again given that we have a limited number of observations in some of our models, our selection of four lags provides a reasonable benchmark and is consistent with other studies in the literature (Peersman and Straub, 2009).

\section{House Price Fluctuations: Basic Facts}

We start this section with a brief discussion of the main features of fluctuations in house prices, equity prices, credit, interest rates and output. We then study the degree of comovement between house prices, output and other financial variables within countries using simple correlations. We conclude with a study of the synchronization of house prices and other variables across countries using different approaches.

\section{IV.1. Growth, Volatility and Comovement}

House prices in advanced economies grew almost at the same pace as economic activity but the growth rate of house prices has accelerated over recent decades (Table 2). Over the past four decades, real house prices have grown at an average rate of $2 \frac{1}{4}$ percent per year, slightly slower than the growth of output. The growth of house prices differs significantly across countries (ranging from less than $1 / 2$ percent per year in Germany, Japan, and Switzerland to over 3 percent per year in Spain and the United Kingdom) and over time.

House prices are volatile with an average standard deviation of almost $71 / 2$ percent per year. The volatility of house prices has fallen slightly over time, partly reflecting the widespread reduction in the volatility of inflation and output in advanced countries prior to the crisis. House price volatility also varies significantly across countries, and is generally higher the more rapid the rate of underlying house price growth, although this relationship has weakened over the past decade. Compared with equity prices, house prices exhibit slower growth and less volatility.

An overview of simple correlations between house prices and some key macroeconomic and financial variables points to three key results (Table 3): First, house prices in advanced economies are procyclical, rising in expansions and falling in recessions. The average correlation between house prices and output is close to 0.5 over 1971-2011. The strength of the comovement between house prices and output, however, varies across countries, being weakest in Australia, Canada, Italy, and Switzerland, and strongest in Denmark, Finland, Ireland, and the United Kingdom. The procyclicality of house prices can be a reflection of strong linkages between housing market and private sector 
absorption (particularly residential investment). However, there does not appear to be evidence of a strong lead/lag pattern between house prices and economic activity (Table 4).

Second, there is a relatively high degree of comovement between house prices and credit (Table 3 ). The strong relationship can be a reflection of that housing is used as collateral in mortgage lending and that house price movements affect the borrowing capacity of households and firms. There is also evidence that credit often leads house prices, consistent with the findings of Mendoza and Terrones (2008). Third, there appears to be virtually no contemporaneous correlation between housing and equity prices and between housing and interest rates (Table 4). However, house prices often lead movements in equity prices (see also Quan and Titman (1998)). The lack of comovement between house prices and interest rates suggests that the availability of credit (especially during periods of lax lending standards) might be one of the dominant drivers of house price movements in advanced economies. Indeed, the recent house price boom prior to the global financial crisis coincided with a period of ample liquidity in the financial sector.

\section{IV.2. Synchronization of House Prices}

The world economy has become increasingly more integrated over the past two and a half decades, reflecting rising trade and financial linkages. Economic theory does not provide clear guidance concerning the impact of increased trade and financial linkages on the degree of business-cycle synchronization (Kose, Otrok and Prasad, 2012). However, some researchers have argued that increased international linkages have led to more synchronized business cycles (Hirata, Kose, and Otrok, 2012). Indeed, the degree of comovement of output growth across advanced economies has increased over the globalization period. With increasingly integrated financial markets, asset prices, credit and interest rates across advanced countries have also become more synchronized (Table 5). The average cross-country correlation of house prices is close to 0.2. This finding is consistent with those reported previously in the literature for other sample periods. In addition, house prices have become more synchronized over time. The increase in the degree of synchronization has been especially pronounced over the last six years, as house prices in several advanced economies have fallen since 2006.

Figure 3 presents the distributions of cross-country correlations of house prices, equity prices, credit and output for each sub-period and the full sample. These figures show that the temporal increase in the degree of correlations in these variables is statistically significant over time. These results are consistent with the growing evidence that house prices in advanced economies have moved in tandem, at least during certain periods (Claessens, Kose, and Terrones (2012) and Helbling and Terrones (2003)). The recent increase in the degree of synchronization of house prices coincided with similar developments in the real and financial sectors across advanced economies, e.g., increased degree of synchronization of national business cycles.

In addition to simple correlation statistics, we study the degree of synchronization of house prices across countries using the concordance index developed by Harding and Pagan (2002b). This index measures the fraction of time that the two series are in the same phase of their respective cycles. This definition implies that the two series are perfectly procyclical (countercyclical), if the concordance index is equal to unity (zero). To analyze the degree of synchronization of house prices and other 
variables across countries, we first compute the concordance statistic for each country pair, and then calculate the median of the relevant statistic for each variable.

Temporal changes in the degree of synchronization based on the concordance metric align well with our findings based on correlations. For the full sample, cycles in the real economy display the highest degree of synchronization, whereas housing cycles exhibit the lowest degree (Table 6). The degree of concordance for all variables has increased over time. In the case of house prices, for example, the fraction of synchronized cycles has increased from 51 percent to more than 63 percent.

\section{IV.3. Variance Explained by Common Factors}

We next study the fraction of variance explained by the common factors to get a better sense of the synchronization of house price fluctuations. As explained earlier, we estimate the first principal component to identify the global factor in each variable. The global factor explains almost one-third of the variation in the growth rate of house prices (Table 7). Perhaps more importantly, the fraction of the variance of house prices explained by the common factor has increased over time from about 20 percent during the pre-globalization period to about 35 percent during the globalization period. The common factor also plays a sizable role in explaining the variation in output and other financial variables. In parallel to our previous findings, the common factor of each variable has become more important over time. ${ }^{10}$

The impact of global factors on house prices varies across individual countries. For example, in the globalization period, global factors appear to explain about 75 percent of house price movements in the United Kingdom and the United States, but only about 10 percent in New Zealand. We run some preliminary regressions to understand how country characteristics relate to the variance of national house prices explained the global factor by focusing on the following explanatory variables: the level of financial integration, population density, development of local mortgage markets, and ownership ratios. Our results indicate that the variance of national house prices due to the global factor is positively associated with the degree of financial integration and negatively associated with the population density. Other studies report that the global factor of house prices is positively correlated with the depth of mortgage markets and gains in home ownership ratios (Terrones and Otrok, 2004).

There have also been structural changes in the functioning of financial markets, due to various financial market reforms, that can lead to more or less synchronized movements in housing markets. The financial sector reform across advanced economies has varied in speed and depth. This has resulted in segmented-mortgage markets, which has probably affected the extent of synchronization of credit and housing markets across countries.

We also examine the cross-country correlations of the common factors to get a sense of the degree of synchronization of global aggregates (Table 8). There are two major observations: First, the common factor of house prices is highly correlated with the factors of credit and output for the full sample.

\footnotetext{
${ }^{10}$ We also examine the linkages between global factors of house prices, output, and other financial variables using a series of Granger causality tests. These tests indicate that there are bidirectional causation linkages in the Granger sense between most of our global factors.
} 
Second, the correlations between the common factor of house prices and the factors of credit and output have declined over time. These observations suggest that, at the global level, the links between housing markets and real activity have become weaker over time and house price dynamics have increasingly moved away from fundamentals. In the case of credit, the increased integration of housing finance into the broader financial sector during the globalization period has probably made credit less important in driving house prices in the advanced economies.

Finally, we assess whether our findings with respect to the basic features of fluctuations in house prices are influenced by the crisis period after 2007. This is obviously a concern given that this period witnessed highly synchronized business and financial downturns across advanced countries. We reestimate all of the statistics for the Great Moderation period for 1985:1-2007:4. We find that our headline results with respect to the synchronization of house prices are mostly preserved for the Great Moderation period. For example, we find that the concordance of housing cycles went up from 51 percent in the pre-globalization period to 64 percent during the Great Moderation period.

\section{Explaining House Price Fluctuations}

In the previous section, we established that house price movements across the world are synchronized to some degree. This is an interesting empirical fact in and of itself, but it naturally leads to the

question of why they are synchronized. In this section, we study how various shocks affect global house prices.

\section{V.1. Identification of Structural Shocks}

The identification of structural shocks (monetary policy shocks, productivity shocks, etc.) in the VAR framework has generated an enormous literature over the years. In identifying shocks, we attempt to include the same variables in each model we use to the greatest extent possible. However, due to the different data needed to implement sign restrictions for different shocks, there is some variation across models. The shock identification methods we employ are not unique to this paper as the restrictions imposed have been shown elsewhere to be derived from economic theory. We briefly provide some intuition to motivate the theory but do not present a discussion of the corresponding structural models.

Our first identification strategy uses a simple recursive structure. The variables we include in the VAR are the global components estimated in the previous section. The order we use is the following: output, house prices, interest rates, credit, and equity prices. This setup is motivated by the fact that real variables are likely to adjust slower than do financial market variables, so the order is from most slowest temporal adjustment to the fastest. The VAR with this identification scheme provides preliminary evidence on what types of global shocks are likely to matter and motivates the more structural identification approach that we employ next. It also helps to reconcile our results from the identification of structural shocks with the related literature that has used a recursive structure.

Our second identification strategy involves the use of a set of sign restrictions imposed on impulse responses following Uhlig (2005). This identification approach allows us to produce impulse responses that are qualitatively consistent with standard theoretical predictions. To impose sign restrictions, we draw random impulse vectors and retain only those that meet the restrictions on the sign of the 
response for some of the variables in the model. Implementation of this method requires us first to draw a set of parameters from the posterior of the VAR model. We then draw a random impulse response vector which is retained if it meets the sign restrictions implied by theory. We continue drawing until we have 5,000 accepted impulse response vectors. ${ }^{11}$ We keep the horizon for sign restrictions at four quarters to maintain symmetry across models we use. The selection of four quarters also captures the idea that the impact of each shock lasts for at least a year. ${ }^{12}$ We now briefly discuss the identification of productivity, monetary, credit and uncertainty shocks we employ.

Productivity shocks. These shocks have a long history in economics as being an important driver of both cycles and trend movements in output. In the international business cycle literature, Crucini, Kose and Otrok (2011) find that much of the common cycle in output can be attributed to fluctuations in common productivity. We study instead the role of productivity in driving global house prices. Towards this objective, we use the identifying restrictions derived in Peersman and Straub (2009). They show that, for a wide class of DSGE models, following a positive productivity shock, output rises and inflation falls. Productivity increases lower marginal cost which, in turn, drives down inflation in a New Keynesian model. ${ }^{13}$ The FAVAR model used to study productivity shocks includes the growth rates of equity prices, reserves, output and house prices as well as the levels of long- and short-term interest rates and inflation.

Monetary policy shocks. As we discuss in the introduction, there is a large literature analyzing the potential impact of monetary policy shocks on house prices. By changing interest rates and the cost of borrowing, central banks may affect house prices. To identify monetary policy shocks, we use the sign restrictions following Uhlig (2005). The restrictions are that, in response to the monetary shock, shortterm interest rates rise, reserves fall, and inflation declines (for the first 3 periods). The FAVAR model we use to examine these shocks is similar to the previous one, except we use global credit growth instead of the growth of equity prices.

Credit market shocks. The recent global financial crisis is suggestive that developments in credit markets are important for economic activity. Helbling and others (2011), for instance, examine the implications of credit market shocks for the evolution of the growth of global output. They document that while global credit supply shocks on average do not seem to have a significant impact on global output; they do matter in periods with elevated financial stress and difficulties in credit markets. There appears to be a tight link between credit and housing markets in light of the correlations we reported in

\footnotetext{
${ }^{11}$ If we reach 1,000,000 draws without getting 5,000 accepted draws, we would stop. However, this never occurred for the models used in this study.

${ }^{12}$ The selection of horizon length closely follows Peersman and Straub (2009) who also use the same length to identify productivity shocks for the Euro area. There are some studies that keep the sign restriction horizon shorter than the one we use. For instance, Uhlig (2005) identifies monetary policy shocks by keeping the sign restrictions horizon at 2 quarters. In the context of credit market shocks for the U.S., Meeks (2012) identifies a credit shock by imposing sign restrictions on spreads for 2 quarters and those on defaults for 12 quarters. We have conducted sensitivity exercises to check the robustness of our results to alternative identification restrictions and horizon assumptions. All of our main results are robust to these variations.

${ }^{13}$ They argue that wages should rise following a positive productivity shock. This is true in models with Walrasian labor markets. However, Otrok and Pourpourides (2011) find that micro-level wage data is inconsistent with the prediction of models with Walrasian labor markets. We do not impose this restriction since it is not robust.
} 
the previous section. We use the sign restrictions proposed by Meeks (2012) to identify credit market shocks. The restrictions imply that, after a negative credit supply shock, credit falls while the spread between low grade and high-grade corporate bond yields rise. An additional restriction that Meeks proposes is that default rates do not rise. This restriction is designed to ensure that the shock is a pure supply shock and not an endogenous response of lenders to adverse economic news.

An important data limitation we face is that we have default and spread data only for the United States. Given that transactions in the U.S. markets constitute a substantial fraction of transactions in global financial markets, we use these series as proxies for the world in our FAVAR models. In addition, since the default series are available since the late 1980s only, we are unable to run our models for the pre-globalization period with the credit shocks. The FAVAR we utilize to study credit market shocks is similar to the previous one except that we use spreads and default rates instead of reserves and longterm interest rates. In other words, our model includes the following variables: growth rates of credit, spreads, defaults, output, house prices, and the levels of short-term interest rates and inflation.

Uncertainty shocks. Recently, there has been significant interest in understanding the role uncertainty plays in driving macroeconomic fluctuations. In theory, there are multiple channels through which macroeconomic uncertainty can have an impact on output. On the demand side, for example, when faced with high uncertainty, firms reduce investment demand and delay their projects as they gather new information, because investment is often costly to reverse (Bernanke, 1983; Dixit and Pindyck, 1994). Households' response to high uncertainty is similar to that of firms; they reduce their consumption of durable goods as they wait for less uncertain times. On the supply side, firms' hiring plans are also negatively affected by higher uncertainty reflecting costly adjustment of personnel. Moreover, financial market imperfections can amplify the negative impact of uncertainty on activity.

Recent empirical studies also confirm the significant role of uncertainty shocks. For example, Bloom (2009) finds that increases in uncertainty have a pronounced negative impact on output and employment. Uncertainty shocks account for about one-third of business cycle variation in advanced economies and up to half of cyclical volatility in emerging market countries, implying that these shocks play a sizable role in driving the dynamics of recessions and expansions (Bloom and others, 2012; Baker and Bloom, 2012; Carrière-Swallow and Céspedes, 2011). Other relevant research concludes that shocks associated with uncertainty were one of the primary factors that led to the Great Recession (Stock and Watson, 2012).

We follow Bloom (2009) and identify the shocks using a recursive scheme with the following ordering: equity prices, uncertainty, the short- and long-term interest rates, house prices, inflation and output. There are four main differences between our model and the setup of Bloom (2009). First, he uses data on wages, employment, and hours instead of interest rates and house prices. Second, his data series are monthly whereas ours are quarterly. Third, he uses HP filtered levels for aggregates with trends while we use growth rates. Finally, we estimate a measure of global uncertainty shock using the first principal component estimated from individual uncertainty series of the G-7 countries whereas he focuses on uncertainty shocks in the United States. 


\section{V.2. Evidence on the Sources of House Price Fluctuations}

\section{V.2.1. Recursive Identification}

Global interest rate shocks have a significant but delayed negative impact on global house prices (Figure 4A). This result is consistent with earlier findings in the literature analyzing the impact of national interest rate shocks on domestic house prices (Kuttner, 2012). The result is commonly interpreted by some researchers as evidence of that monetary policy drives house prices.

Our interpretation of this result is that surprise shocks to interest rates-which may be market driven or originate from the actions of the Central Bank-drive down house prices by increasing the cost of borrowing. Mortgage credit is indeed the most important source of financing that households have in many of these countries. However, there are important differences across countries with the Netherlands, United States and United Kingdom showing the highest mortgage-to-GDP ratios and France, Italy and Japan showing the lowest.

Considering these cross-country differences, we further analyze the role of interest rate shocks in driving house prices by conducting two exercises. First, we check the impact of global interest rate shocks at the country level. Although the immediate response of national house prices to interest rate shocks is negative in most cases, there is substantial variation in the magnitude of responses across countries, as shown in Figure 4B. Second, we estimate the same FAVAR model using the series of G-7 countries (instead of our benchmark sample of 18 countries). We again find that interest rate shocks have a significant negative impact on house prices during the full sample and globalization periods. ${ }^{14}$ We present results based on a more rigorous identification strategy for monetary policy shocks in the next sub-section.

The response of global house prices to an increase in global credit is positive and significant. Not surprisingly, in both sub-periods, when there is robust growth in credit, house prices tend to appreciate. House prices seem to not respond to innovations to equity returns in a significant way. This is probably a reflection of the low contemporaneous correlation between these two asset prices we documented earlier. Shocks to global output have a small positive impact on global house prices. We interpret this as suggesting that robust economic growth tends to provide modest support for housing markets.

Table 9 presents the variance decompositions for global house prices and output. In the full sample, global interest rate shocks account for close to 30 percent of the movements in house prices, with credit contributing a more modest 10 percent. Innovations to house prices themselves account for about half of the variation in house price series. We view this as the fraction of movements in global house prices that we are unable to explain with the FAVAR model.

\footnotetext{
${ }^{14}$ In addition, we consider how our results change, if we use a sample of countries for which the global housing factor explains a larger role in explaining national house prices. Specifically, we select countries for which the global house factor accounts for more than 25 percent of the variance of national house prices during the globalization period. We repeat all of our exercises with this sample of ten countries. Although there are changes in our quantitative findings, the headline results we report here do not change in any significant way.
} 
We also consider some sensitivity exercises to assess the robustness our findings. First, we estimate our models for the Great Moderation (1984-2007) period. Second, we consider the ordering of financial variables and re-estimate our models. The results of these exercises do not lead to any major changes in our headline findings. In addition, we undertake a simple exercise to analyze the transmission of national shocks to global house prices. Specifically, we check the responses of global house prices to country-specific shocks by using the national variables (instead of global ones) along with the global housing factor in our models. Our findings are mostly consistent with the headline results reported here but there are some differences across countries, as one would expect. This exercise suggests that, at least in the case of large countries, such as the United States, the nation specific shocks can generate impulse responses similar to those associated with their global equivalents.

Our conclusion from these exercises then is that income whether earned (output) or through portfolio (equity returns) have a muted impact on global house prices. On the other hand, the availability of credit and the cost of that credit, i.e., interest rates, appear to have significant and persistent effects on house prices in most specifications. These results are reduced form in the sense that each shock is likely to be a combination of underlying structural shocks. However, we find the exercise useful for at least two reasons. First, much of the literature uses this identification scheme and then applies a structural interpretation to the results. This interpretation has important consequences as it is often employed in the context of policy discussions. By comparing the results from such an exercise with a more robust identification approach as we do in the next sub-section, we can present a better understanding of the current literature. Second, reduced form evidence is quite valuable in suggesting which structural shocks are likely to matter and hence provides a roadmap for progress.

\section{V.2.2. Identification with Sign Restrictions}

Monetary policy shocks. Since there is a general perception in the literature that interest rate shocks are an important driver of house prices, as our findings mostly confirmed above, we begin with a discussion of our results based on a formal identification of global monetary policy shocks. The results indicate that monetary policy shocks do not appear to have a significant impact on house prices at the global level (Figure 5A). This is in contrast to the earlier result that interest rate shocks do drive house prices. These findings suggest that the surprise movements in interest rates that drive house prices seem not to be originating solely from the actions of central banks. Monetary policy shocks explain 12 percent of house price variation in the full sample period (Table 10A). However, the importance of monetary policy shocks in explaining house prices has not changed much over time.

Why do we find that interest rate shocks appear to play an important role in driving house prices but monetary policy shocks do not? An interest rate shock is associated with an unexpected movement in interest rates in our FAVAR model, which is not caused by shocks to income, house prices, or credit. Moreover, interest rate shocks can be driven by factors other than just monetary policy decisions. For example, interest rates can move unexpectedly due to changes in tax policies, changes in policies with respect to debt accumulation, spillovers associated with international crises, and possibly many other reasons. Our results indicate that the monetary policy part of the reduced form innovation to interest rates is not significant, but shocks stemming from the "non-monetary policy" part are important. Our finding of the "insignificant" role of monetary policy helps eliminate one of the main suspects seen as a main driving force of house prices. It also provides a cautionary tale when interpreting interest rate 
shocks in GVARs as being related to monetary policy. For the most part, interest rate shocks and monetary policy shocks appear to be different.

The impact of monetary policy shocks on the global level differs somewhat from the results reported by Del Negro and Otrok (2007) for the United States. They find that the impact of a monetary shock on house prices is statistically significant. A major reason for the difference is that there are probably more and larger shocks to country specific policy in the context of the United States then there are global shocks to monetary policy, i.e., a shock that is simultaneous across countries. The frequency and size of monetary policy shocks in the United States likely lead to sharper results. Another reason could be that they study the pre-crisis period (1986-2005) but we consider a much longer period, including the recent crisis. The impulse responses to a monetary shock reported here for the globalization period have the same sign as the one in Del Negro and Otrok (2007), but it is not statistically significant. On the other hand, they find that monetary shocks account for only 10 percent of house price volatilityvery close to our finding of 12 percent.

Credit shocks. We next study the importance of credit supply shocks (Figure 5B). The responses of house prices to these shocks are essentially zero. Credit shocks have a negative and significant impact on output for one year. They account for 14 percent of house price growth and 12 percent of output growth. These variance shares also appear to be stable over time. The reduced form credit shocks identified in Figure 4A had credit shocks playing a positive role on house prices. In contrast, we here find that exogenous supply side movements in credit have not been a significant driver of house prices.

One interpretation of this finding is that credit markets usually function well and shocks in these markets are often relatively small. Hence, shocks in credit markets do not on average appear to drive fluctuations in house prices. This is similar to what Helbling and others (2011) find in the case of the impact of credit shocks on the global business cycle. They report that credit supply shocks affect fluctuations in global output especially during severe disruptions in credit markets (as it happened during the 2007-09 global financial crisis and during the credit crunch in the United States in the early $1990 \mathrm{~s}){ }^{15}$

Why, then, do we find that credit shocks matter in the earlier section using the recursive identification strategy? In Section III, we document that credit and house prices move together. The result in Section IV then is capturing these correlations in a reduced form setting. It is not appropriate, however, to place a structural interpretation to the previous result we reported. Additionally, our finding here implies that credit supply shocks do not matter much. It may be the case that credit demand shocks have an impact on house prices. A possible extension is to use the framework in Eickmeier, Gambacorta, Hofmann (2012) to separate out the impact of shocks stemming from credit supply and credit demand.

Productivity shocks. Not surprisingly, global productivity shocks tend to drive up global output (Figure 5C). However, their impact on output, despite being significant, is quite small. These shocks

\footnotetext{
${ }^{15}$ The important role played by credit market disturbances in explaining the severity of certain recessions is also reported by some recent studies (see Perri and Quadrini (2010); Mian and Sufi (2010) and Claessens, Kose, and Terrones $(2009,2010))$.
} 
tend to have a positive but insignificant effect on house prices. Given that the impact of shocks to output growth on house prices is modest, the insignificant impact of productivity shocks on house prices is not surprising. That is, productivity here matters mostly because it drives up income, which in theory would allow bidding up house prices. In practice, however, this economic mechanism appears to be weak. ${ }^{16}$

\section{V.2.3. The Impact of Uncertainty Shocks}

To study uncertainty shocks, we use a recursive identification strategy and include the following variables in our FAVAR model: equity, uncertainty, interest rates, house prices, and output. We consider uncertainty as an exogenous variable in the same spirit that productivity is often considered exogenous in both VAR identification schemes and in structural models. Causality between uncertainty and the business cycle is difficult to establish - does uncertainty drive real and financial variables, or do developments in real and financial markets lead to uncertainty? Although empirical findings on this question are mixed, economic theory points to clear channels through which exogenous uncertainty shocks can have a negative impact on growth, as discussed earlier. ${ }^{17}$

We present the impulse responses of global house prices, equity prices and output to uncertainty shocks in Figure 6A. These shocks reduce output for the full sample period and globalization period. This shows that the results by Bloom (2009) for the U.S. holds for the global economy as well, though the impact is stronger during the globalization period. ${ }^{18}$ Our results are a bit weaker in terms of the size of the response relative to Bloom but the shapes are similar. These shocks account for around 10 percent of output variation during the full sample period (Table 11A). Uncertainty shocks also have a negative and significant impact on equity prices.

The impact of uncertainty shocks on global house prices is not significant in the full sample. In the first sub-period, the impact is modest and negative. In the second sub-period, the response is positive, significant and of long duration. However, when we focus on the G-7 countries, this shock becomes significant for both the full sample and globalization periods (Figure 6B). More surprisingly, uncertainty shocks tend to drive up house prices in the G-7 countries. They account for 30 percent of house price variation in the G-7 during the globalization period (Table 11B). In other words, uncertainty plays a central role in explaining why there is a common cycle in house prices. One reason why this might be true is that uncertainty seems to be quite common across countries. The average correlation of country level uncertainty with the G-7 factor is 0.81 , while the average correlation of uncertainty across G-7 country pairs is 0.62 .

\footnotetext{
${ }^{16}$ An alternative approach to identifying TFP shocks is to order productivity first in a VAR model where shocks are identified using a recursive scheme. This of course requires a productivity series, which we have readily available for the United States, but not the world. We analyze the implications of productivity shocks in the United States following this approach. The results are quite similar to those from the FAVAR model we report here in that productivity shocks have a minimal impact on house prices.

${ }^{17}$ Bachmann and Moscarini, (2011) find that the direction of causality runs from recessions to uncertainty. In contrast, Baker and Bloom (2011) offer evidence using disaster data as instruments, that the causality runs from uncertainty to recessions, and Bloom and others (2012) report that growth does not cause uncertainty.

${ }^{18}$ Our results also echo the findings in a broader area of research on the negative impact of macroeconomic and policy volatility on economic growth (Kose, Prasad, and Terrones, 2006; Fatas and Mihov, 2012).
} 
We interpret these results as follows. First, uncertainty seems to move in tandem in the G-7 countries. Second, uncertainty seems to matter for house prices. These two facts lead to global innovations in uncertainty accounting for a significant amount of movements in the global component of house prices for the G-7 countries. Third, the role that uncertainty plays in explaining house price movements is more pronounced during the globalization period. This may be due to the fact that stock market participation has increased over this period and that housing market has benefited from other vehicles of financing (other than conventional mortgages).

Lastly, our finding that the increase in stock market uncertainty drives up house prices is likely because when there is heightened uncertainty in a risky asset people resort to buying more of an asset that is perceived to be relatively safer. For example, in currency markets during periods of global crisis, investors move into the "safer" currency, which is the dollar. Is housing a safe asset? While recent experience suggests otherwise, the empirical facts we report in the previous section find that house prices are generally less volatile (or safer) than equity prices during the globalization period. It would be natural then that in a time of uncertainty that the demand (and price) for houses would increase because of the decline in demand for volatile equities. While we are unaware of micro level evidence of this interpretation, we think that it is a result worth further exploration.

\section{Conclusion}

We study house price fluctuations in advanced countries over the past four decades. We focus on two specific questions. First, how synchronized are housing cycles across countries? Second, what are the main shocks driving movements in global house prices?

To answer the first question, we present an extensive analysis of the degree of comovement of house prices across countries using various metrics, including basic correlations, concordance indices, and variance decompositions of national house prices into global and country-specific components. Our analysis of basic correlations leads to following observations. First, house prices in advanced economies tend to move together. Second, house prices have become more synchronized over time. The degree of concordance of housing cycles has increased from 51 percent during the preglobalization period to more than 63 percent in the globalization period. Lastly, the fraction of variance of house prices explained by the global house price factor has increased from about 20 percent during the pre-globalization period to 35 percent in the era of globalization.

Next, we employ various FAVAR models to examine the main shocks driving global house price fluctuations. To identify these shocks, we use two identification schemes commonly used in the literature - a recursive method and a sign restriction method. The first method is useful to gain a better understanding of the previous results in the literature and points to which structural shocks are likely to matter. However, it does not allow us to assign a structural interpretation to our findings. The second method relies on sign restrictions borrowed from a wide range of general equilibrium models and allows us to draw structural interpretations from the results.

We report four major results about the sources of global house price fluctuations. First, global interest rate shocks tend to have a significant effect on global house prices in most specifications when these 
shocks are identified using a recursive scheme. This finding has led some observers to argue that the use of monetary policy of low interest rates prior to the 2007-09 global financial crisis has been an important driver of house prices in advanced economies, especially in the United States (Taylor, 2008). However, it is not clear what drives interest rate movements when one simply relies on the recursive identification. Are they market driven? Or are they the results of policy decisions by central banks?

To shed light on this issue, we turn to the identification of global monetary policy shocks with sign restrictions. This brings us our second finding: global monetary policy shocks per se do not appear to have a sizeable impact on global house price movements. In other words, monetary policy cannot be the sole reason explaining the boom-bust behavior of house prices in advanced economies over the last decade. In addition, considering our first finding, this result also implies that surprise movements in interest rates that drive house prices cannot be exclusively explained by changes in monetary policy.

Third, neither productivity nor credit shocks appear to have a significant impact on house price movements. Productivity shocks have a small impact on output, and shocks to output tend to have a modest influence on the growth rate of house prices. These in turn imply that the role of productivity shocks in explaining global house price movements is small. With respect to the minor role of credit shocks, we argue that credit markets often function well and shocks stemming from these markets are on average small. The implication is that shocks originating in credit markets have on average a small impact on house prices. However, this result does not preclude the possibility that when there are sizeable movements in credit-during periods of credit booms or crunches, for example-credit market shocks can lead to significant fluctuations in house prices, as the global economy witnessed over the past decade.

Last, but not the least, we find that uncertainty shocks tend to have a significant impact on global house price movements. Specifically, one third of the global cycle in house prices can be attributed to uncertainty shocks in the sample of G-7 countries. This is an economically large role for a single shock to explain, and hence an important empirical fact. It is difficult to measure uncertainty because of its latent nature. We employ a widely used measure here and consider the importance of uncertainty shocks associated with the volatility of stock returns. From a mechanical perspective, uncertainty series are highly correlated across countries implying that they have a significant common component. This component appears to be important in explaining the common variation in house prices. Another interpretation of our finding is that when the volatility of stock returns increases, agents appear to shift their portfolio composition towards safer assets, such as housing. While housing may no longer be perceived as a relatively safe asset by many, it was, at least for an extended period, before 2007 .

Our results from various time-series models point to the necessity of a deeper study of sources of house price movements. We consider four possible avenues for future research: First, it is important to consider the roles played by a wider range of shocks in explaining house prices, including shocks associated with fiscal and financial policies, in the context of time-series models with heterogeneity and nonlinearities. This will require designing models that allow nonlinear feedback effects between policy choices and interactions among the real economy, housing sector, and financial markets. Second, although we provide preliminary evidence about the sources of common movements in house prices, we do not articulate why house prices have become more synchronized over time. A natural next topic to explore is a deeper analysis of differential effects of shocks and structural features of 
countries, including their linkages through the banking system, on the temporal changes in the degree of synchronization of house prices.

Third, we study the average impact of shocks on house prices over the past 40 years. It would beneficial to go a step further and study how shocks affect house prices during certain episodes. For example, one would expect that house prices respond differently to shocks during periods of pronounced cycles in credit and housing markets, such as credit booms/crunches and house price booms/busts. Understanding the dynamics of house prices during such episodes would require designing counterfactuals to study the implications of the presence (or absence) of certain shocks around these periods. Finally, it would also be useful to analyze the roles of these shocks using dynamic stochastic multi-country general equilibrium models that can account for spillovers across housing markets in different countries. 


\section{References}

Alvarez, Luis J., G. Bulligan, A. Cabrero, L. Ferrara and H. Stahl, 2010, "Housing cycles in the major euro area countries," Working Paper, Banque de France.

Aoki, Kosuke, James Proudman, and Gertjan Vlieghe, 2004, "House Prices, Consumption, and Monetary Policy: A Financial Accelerator Approach," Journal of Financial Intermediation, Vol. 13, No, 4, pp. 414-35.

Assenmacher-Wesche, Katrin, and Stefan Gerlach, 2010, "Financial structure and the impact of monetary policy on property prices," Working Paper, Goethe University of Frankfurt.

Baker, Scott, and Nicholas Bloom, 2011, "Does Uncertainty Drive Business Cycles? Using Disasters as a Natural Experiment," Working Paper, (Stanford University).

Baker, Scott, Nicholas Bloom, and Steven J. Davis, 2012, "Measuring Economic Policy Uncertainty," Working Paper, (Stanford University).

Beltratti, A., and C. Morana, 2010, "International house prices and macroeconomic fluctuations," Journal of Banking \& Finance, Vol. 34(3), pp.533-545.

Bernanke, Ben, Jean Boivin, and Piotr S. Eliasz, 2005, "Measuring the Effects of Monetary Policy: A Factor-augmented Vector Autoregressive (FAVAR) Approach," The Quarterly Journal of Economics, Vol. 120, No.1, pp. 387-422, January.

Bernanke, Ben, Mark Gertler, and Simon Gilchrist,1999, "The Financial Accelerator in a Quantitative Business Cycle Framework," in Handbook of Macroeconomics, Vol.1C, Handbooks in Economics, Vol. 15., pp. 1341-93.

Bernanke, Ben and Mark Gertler, 1989, "Agency Costs, Net Worth, and Business Fluctuations," American Economic Review, Vol. 79, pp.14-31.

Bernanke, Ben, 1983, "Irreversibility, Uncertainty and Cyclical Investment," Quarterly Journal of Economics, Vol. 98, pp. 85-106.

Bloom, Nicholas, Max Floetotto, Nir Jaimovich, Itay Saporta-Eksten, and Stephen Terry, 2012, "Really Uncertain Business Cycles," NBER Working Paper No. 18245.

Bloom, Nicholas, 2009, “The Impact of Uncertainty Shocks,” Econometrica, Vol. 77(3), pp. 623-685.

Calza, Alessandro, Tommaso Monacelli, and Livio Stracca, 2009, "Housing finance and monetary policy,” ECB Working Paper.

Cardarelli, R., T. Monacelli, A. Rebucci, and L. Sala, 2008, "Housing Finance, Housing Shocks, and the Business Cycles: Evidence from OECD countries," IADB Working Paper.

Carrière-Swallow, Yan, and Luis Felipe Céspedes, 2011, "The Impact of Uncertainty Shocks in Emerging Economies," Working Paper No. 646, (Santiago: Central Bank of Chile).

Carstensen, K., Hulsewig, O. and Wollmershauser, T., 2009, "Monetary policy transmission and house prices: European cross country evidence," Working paper d.7.4, European Commission.

Case, Bradford, William Goetzmann, and Geert Rouwenhorst, 1999, "Global Real Estate Markets: Cycles and Fundamentals," Yale International Center for Finance, WP No. 99-03.

Cesa-Bianchi, Ambrogio, 2011, "Housing Cycles in the Global Economy," Working Paper, InterAmerican Development Bank.

Claessens, Stijn, M. Ayhan Kose, and Marco Terrones, 2012, "How do Business and Financial Cycles Interact?” Journal of International Economics, Vol. 87, pp.178-190.

Claessens, Stijn, M. Ayhan Kose, and Marco Terrones, 2010, "Financial Cycles: What? How? When?" NBER International Seminar on Macroeconomics 2010, in Richard Clarida and Francesco Giavazzi eds., University of Chicago Press, pp.303-343. 
Claessens, Stijn, M. Ayhan Kose, and Marco Terrones, 2009, "What Happens During Recessions, Crunches, and Busts?" Economic Policy, October, pp. 653-700.

Crucini, Mario, M. Ayhan Kose, and Chris Otrok, 2011. "What Are the Driving Forces of International Business Cycles?" Review of Economic Dynamics, Vol. 14, pp. 156-175.

Cunningham, Rose, and Ilan Kolet, 2007, "Housing Market Cycles and Duration Dependence in the United States and Canada," Working Paper, Bank of Canada.

Del Negro, Marco, and Otrok, Christopher. 2007, "99 Luftballons: Monetary policy and the house price boom across U.S. states," Journal of Monetary Economics, Vol.54 (7), pp. 1962-1985.

Eickmeier, Sandra, Leonardo Gambacorta, Boriss Hofmann, 2012, "Understanding Global Liquidity," BIS Working Paper.

Fatas, Antonio, and Ilian Mihov, 2012, "Policy Volatility, Institutions and Economic 24 Growth," Review of Economics and Statistics, (forthcoming).

Feroli, Michael, Ethan S. Harris, Amir Sufi, and Kenneth D. West, 2012, "Housing, Monetary Policy, and the Recovery," Chicago Booth Research Paper, No. 12-16.

Gertler, Mark, 1988, "Financial Structure and Aggregate Economic Activity: An Overview," Journal of Money, Credit and Banking, Vol. 20, No. 3, pp. 559-588.

Gilchrist, Simon, Vladimir Yankov, and Egon Zakrajšek, 2009, "Credit Market Shocks and Economic Fluctuations: Evidence from Corporate Bond and Stock Markets," NBER Working Papers 14863.

Bradford, Case, William Goetzmann, K. Rouwenhorst. 1999, “Global Real Estate Markets: Cycles And Fundamentals," Yale School of Management Working Papers.

Goodhart, Charles and Hofmann, Boris, 2008, "House prices, money, credit, and the macroeconomy," Oxford Review of Economic Policy, Vol. 24(1), pp.180-205.

Gupta, Rangan, Marius Jurgilas, Alain Kabundi, and Stephen M. Miller, 2012, "Monetary policy and housing sector dynamica in a large-scale Bayesian vector autoregressive model," International Journal of Strategic Property Management, Vol. 16, pp. 1-20.

Hall, V.B., C. J. McDermott, and J, Tremewan, 2006, “The Ups and Downs of New Zealand House Prices," Motu Working Paper 06-03.

Helbling, Thomas, Raju Huidrom, M. Ayhan Kose and Chris Otrok, 2011, "Do Credit Shocks Matter? A Global Perspective," European Economic Review, Vol. 55, pp. 340-353.

Helbling, Thomas, and Marco E. Terrones, 2003, "Real and Financial Effects of Bursting Asset Price Bubbles," IMF World Economic Outlook, April, pp.61-94.

Hirata, Hideaki, M. Ayhan Kose and Christopher Otrok, 2012, "Globalization vs. Regionalization," IMF Working Paper, forthcoming.

Hubrich, Kirstin, and Robert J. Tetlow, 2011, "Financial Stress and Economic Dynamics: The Transmission of Crises," unpublished working paper.

Iacoviello, Matteo, 2005, "House Prices, Borrowing Constraints, and Monetary Policy in the Business Cycle," American Economic Review, Vol. 95, No. 3, pp. 739-64.

Igan, Deniz, and Prakash Loungani, 2009, "House prices: Global Correction, Local Consequences," Working Paper, IMF.

Jarocinski, M., and F. R. Smets, 2008, "House prices and the stance of monetary policy," Review, Vol. 1, pp. 339-366.

Kiyotaki, Nobuhiro, and John Moore, 1997, "Credit Cycles," Journal of Political Economy, Vol. 105, No. 2, pp. 211-48 
Kose, M. Ayhan, Christopher Otrok, and Eswar Prasad, 2012, "Global Business Cycles: Convergence or Decoupling?” International Economic Review, Vol. 53, pp. 511-538.

Kose, M. Ayhan, Prakash Loungani, and Marco E. Terrones, 2009, "Out of the Ballpark: The Global Recession of 2007-08 in Historical Context," Finance \& Development, Vol. 25 pp. 25-8.

Kose, M. Ayhan, Christopher Otrok, and Charles H. Whiteman, 2008, "Understanding the Evolution of World Business Cycles," Journal of International Economics, Vol. 75, No. 1, pp. 110-130.

Kose, M. Ayhan, Christopher Otrok, and Charles H. Whiteman, 2003, "International Business Cycles: World, Region, and Country Specific Factors," American Economic Review, Vol. 93, pp. 1216-39.

Kuttner, Kenneth N., 2012, "Low Interest Rates and Housing Bubbles: Still No Smoking Gun," Mimeo, Williams College.

Leamer, Edward E., 2007, "Housing is the business cycle," Proceedings, Federal Reserve Bank of Kansas City, pp. 149-233.

Liu, Zheng, Pengfei Wang, and Tao Zha, 2011, "Land-price dynamics and macroeconomic fluctuations," NBER Working Papers 17045, National Bureau of Economic Research.

Meeks, Roland, 2012, "Do credit market shocks drive output fluctuations? Evidence from corporate spreads and defaults," Journal of Economic Dynamics \& Control, Vol.36 pp. 568-584.

Mendoza, Enrique and Marco E. Terrones, 2008, “An Anatomy of Credit Booms: Evidence from Macro Aggregates and Micro Data," NBER Working Paper No. 14049.

Moench, Emanuel and Serena Ng, 2011, "A hierarchical factor analysis of U.S. housing market dynamics," The Econometrics Journal, Vol. 14, Issue 1, pp. C1-C24.

Monacelli, Tommaso, 2009, "New Keynesian Models, Durable Goods, and Collateral Constraints," Journal of Monetary Economics, Vol.56 (2), pp.242-254.

Otrok, Christopher and Panayiotis M. Pourpourides, 2011, "On the Cyclicality of Real Wages and Wage Differentials," Working Papers 2011-4, Central Bank of Cyprus.

Peersman, Gert, and Roland Straub, 2009, "Technology Shocks And Robust Sign Restrictions In A Euro Area Svar," International Economic Review, Vol. 50, No. 3, pp. 727-50, 08.

Quan, Daniel and Sheridan Titman, 1998, "Do Real Estate Prices and Stock Prices Move Together? An International Analysis," Real Estate Economics, Vol. 27, No.2.

Sa, Filipa, Towbin, Pascal and Wieladek, Tomasz. 2011. Low Interest Rates and Housing Booms: The Role of Capital Inflows, Monetary Policy, and Financial Innovation. Working paper.

Silver, Mick. 2012, "Why House Price Indices Differ: Measurement and Analysis," IMF Working Paper, No. 12/125.

Stock, James H. and Mark W. Watson, 2009, "The Evolution of National and Regional Factors in U.S. Housing Construction," in Volatility and Time Series Econometrics: Essays in Honour of Robert F. Engle, Tim Bollerslev, Jeffrey Russell and Mark Watson (eds), Oxford: Oxford University Press.

Stock, J. H. and M. W. Watson, 2012. "Disentangling the Channels of the 2007-2009 Recession," Brookings Papers on Economic Activity (forthcoming).

Taylor, John, 2008, "The Financial Crisis and the Policy Responses: An Empirical Analysis of What Went Wrong," in A Festschrift in Honour of David Dodge's Contributions to Canadian Public Policy, Bank of Canada, pp. 1-18.

Terrones, Marco E. and Christopher Otrok, 2004, "The Global House Price Boom," World Economic Outlook, September, pp.71-89.

Uhlig, Harald, 2005, "What are the effects of monetary policy on output? Results from an agnostic identification procedure," Journal of Monetary Economics, Vol. 52, No. 2, pp. 381-419. 
Vansteenkiste, Isabel 2007, "Regional housing market spillovers in the US - lessons from regional divergences in a common monetary policy setting," Working Paper Series 708, European Central Bank. 
Appendix I: Database

\begin{tabular}{|c|c|c|}
\hline Variable & De finition & Source \\
\hline Output & Gross Domestic Product, volume; 1971:1-2011:3 & OECD \\
\hline House Prices & $\begin{array}{l}\text { Real house prices; 1971:1-2011:3 (except Austria: 1986:3- } \\
\text { 2011:3) }\end{array}$ & OECD \\
\hline Equity Prices & $\begin{array}{l}\text { Share price (index) deflated using consumer price index; } \\
\text { 1971:1-2011:3 }\end{array}$ & IFS \\
\hline Credit & $\begin{array}{l}\text { Nominal credit deflated using consumer price index; 1971:1- } \\
\text { 2011:3 (except Canada: 1971:1-2011:2, New Zealand: 1971:1- } \\
\text { 2011:2, and U.S.: 1971:1-2011:2) } \\
\text { Nominal credit from IFS is generally titled "Claims on Private } \\
\text { Sector", "Claims on Other Resident Sector", etc. Nominal } \\
\text { credit from Datasteam is generally titled "Loans to Resident } \\
\text { Private Sector", "Lending to Enterprises and Individuals", etc. }\end{array}$ & IFS and Datastream \\
\hline Short-term Interest Rate & $\begin{array}{l}\text { Tresury bill rate (IFS), short-term interest rate (GDS), and } \\
\text { three months interbank offer rate (Haver Analytics) deflated } \\
\text { using inflation rate; 1971:1-2011:3 }\end{array}$ & $\begin{array}{l}\text { IFS, GDS, and Haver } \\
\text { Analytics }\end{array}$ \\
\hline Long-term Interest Rate & $\begin{array}{l}\text { Government bond yield (IFS), long-term interest rates on } \\
\text { government bonds ( OECD), and long-term interest rates } \\
\text { (GDS); 1971:1-2011:3 }\end{array}$ & IFS, OECD, and GDS \\
\hline Uncertainty & Volatility of daily equity prices; $1971: 1-2011: 3$ & GFD \\
\hline Reserves & $\begin{array}{l}\text { Total reserves, 1971:1-2011:3 (except Denmark: 1992:1- } \\
\text { 2011:3, Spain: 1979:4-2011:3, and Sweden: 2001:4-2011:3) }\end{array}$ & $\begin{array}{l}\text { IFS, FRED, and Haver } \\
\text { Analytics }\end{array}$ \\
\hline Credit Spread & $\begin{array}{l}\text { Corporate bond spreads: difference between Moody's } \\
\text { seasoned Aaa and Baa corporate bonds for the U.S.; 1971:1- } \\
\text { 2011:3 }\end{array}$ & Moody's Investor Services \\
\hline Default Rate & Rated U.S. speculative-grade corporate bonds; 1971:1-2011:3 & Moody's Investor Services \\
\hline
\end{tabular}


Table 1. Housing Cycles, Recessions and Recoveries

\begin{tabular}{lccccc}
\hline & $\begin{array}{c}\text { Number of } \\
\text { Events }\end{array}$ & Duration & Amplitude & $\begin{array}{c}\text { Cumulative } \\
\text { Loss }\end{array}$ & Slope \\
\hline A. Recessions without House Price Busts & 73 & 3.27 & -1.72 & -2.43 & -0.51 \\
$\quad$ Recessions with House Price Busts & 40 & $4.28^{* *}$ & -2.35 & $-3.57^{* *}$ & -0.52 \\
Recessions with Severe House Price Busts & 24 & $4.38^{*}$ & $-2.64^{* *}$ & $-5.23^{* * *}$ & -0.72 \\
& & & & & 0.75 \\
B. Recoveries without House Price Booms & 102 & 4.79 & 2.97 & $1.45^{* * *}$ \\
Recoveries with House Price Booms & 13 & $2.08^{* * *}$ & $6.25^{* * *}$ & $1.59^{* * *}$ \\
Recoveries with Strong House Price Booms & 8 & $2.13^{* * *}$ & $7.36^{* * *}$ & & \\
\hline
\end{tabular}

Source: Authors' calculations

Notes: All statistics, except "Duration", correspond to sample medians. For "Duration", sample means are reported. Duration for recessions is the number of quarters between peak and trough. Duration for recoveries is the number of quarters it takes to attain the level of output at the previous peak. The amplitude for recessions is defined as the decline in output from the peak to the trough. The amplitude for recoveries is the one year change in output after the trough. Cumulative loss combines information about the duration and amplitude to measure the overall cost of a recession and is expressed in percent. The slope of a recession is the amplitude from the peak to the trough divided by the duration. The slope of a recovery is the amplitude from the trough to the period where output reached the level at its last peak, divided by the duration. Booms correspond to the observations in the top 25 percent of upturns calculated by the amplitude. Busts correspond to the obsservations in the worst 25 percent of downturns calculated by the amplitude. Recessions, recoveries, housing busts and booms are identified following Claessens, Kose, and Terrones (2012). ${ }^{* * *},{ }^{* *}$, and $*$ denote that recessions (recoveries) with house price busts (booms) are significantly different than those without house price busts (booms) at 1 percent, 5 percent, and 10 percent levels, respectively. 
Table 2. Summary Statistics

\begin{tabular}{|c|c|c|c|c|c|}
\hline & Mean & Volatility & $\begin{array}{c}\text { Coefficient of } \\
\text { Variation } \\
\end{array}$ & Maximum & Minimum \\
\hline \multicolumn{6}{|l|}{ Output } \\
\hline Full Sample & 2.51 & 2.53 & 0.99 & 9.34 & -6.39 \\
\hline Pre-Globalization & 2.82 & $2.74 *$ & 1.03 & 8.90 & -3.29 \\
\hline Globalization & 2.35 & 2.30 & 1.02 & 6.80 & -5.64 \\
\hline \multicolumn{6}{|l|}{ House Prices } \\
\hline Full Sample & 2.20 & 7.48 & 0.29 & 26.40 & -14.63 \\
\hline Pre-Globalization & $1.23 * *$ & 8.05 & 0.15 & 22.09 & -12.94 \\
\hline Globalization & 2.70 & 6.75 & 0.40 & 21.04 & -12.27 \\
\hline \multicolumn{6}{|l|}{ Equity Prices } \\
\hline Full Sample & 4.64 & 24.15 & 0.19 & 79.50 & -49.49 \\
\hline Pre-Globalization & $-0.02 * * *$ & 23.22 & 0.00 & 62.13 & -41.74 \\
\hline Globalization & 7.08 & 23.95 & 0.30 & 74.74 & -46.56 \\
\hline \multicolumn{6}{|l|}{ Credit } \\
\hline Full Sample & 5.30 & 6.66 & 0.80 & 26.46 & -10.01 \\
\hline Pre-Globalization & 4.80 & 6.45 & 0.74 & 20.25 & -7.36 \\
\hline Globalization & 5.56 & 6.32 & 0.88 & 22.56 & -8.02 \\
\hline \multicolumn{6}{|c|}{ Short-term interest rate } \\
\hline Full Sample & -0.15 & 2.29 & -0.07 & 8.38 & -8.02 \\
\hline Pre-Globalization & $0.21 * * *$ & $2.76^{* * *}$ & 0.08 & 7.08 & -6.13 \\
\hline Globalization & -0.34 & 1.88 & -0.18 & 5.47 & -6.52 \\
\hline \multicolumn{6}{|c|}{ Long-term interest rate } \\
\hline Full Sample & -0.10 & 1.30 & -0.08 & 4.01 & -3.95 \\
\hline Pre-Globalization & $0.27 * * *$ & $1.42 *$ & 0.19 & 3.55 & -3.11 \\
\hline Globalization & -0.30 & 1.14 & -0.26 & 3.11 & -3.27 \\
\hline
\end{tabular}

Source: Authors' calculations

Note: Mean indicates the average growth rate. Volatility is the standard deviation of the growth rate. Coefficient of variation is the ratio of the mean to the volatility. Maximum (minimum) is the maximum (minimum) growth rate of each variable. The full sample covers the period of 1971:1-2011:3, the pre-globalization period is the subperiod of 1971:1-1984:4, and the globalization period is the sub-period of 1985:1-2011:3. ***,**,* denote that the statistics in the pre-globalization period are statistically significantly different from those in the globalization period at 1 percent, 5 percent, and 10 percent levels, respectively. 
Table 3. Correlations Across Variables Within Countries

\begin{tabular}{|c|c|c|c|c|c|}
\hline & House Prices & Equity Prices & Credit & $\begin{array}{l}\text { Short-term } \\
\text { interest rate }\end{array}$ & $\begin{array}{l}\text { Long-term } \\
\text { interest rate }\end{array}$ \\
\hline \multicolumn{6}{|l|}{ Output } \\
\hline Full Sample & 0.46 & 0.29 & 0.40 & 0.30 & 0.16 \\
\hline Pre-Globalization & 0.45 & $0.21 * * *$ & $0.5 * *$ & $0.19^{* *}$ & $-0.02 * * *$ \\
\hline Globalization & 0.48 & 0.38 & 0.35 & 0.39 & 0.24 \\
\hline \multicolumn{6}{|l|}{ House Prices } \\
\hline Full Sample & & 0.15 & 0.47 & 0.16 & 0.07 \\
\hline Pre-Globalization & & $0.08 *$ & 0.49 & 0.15 & 0.01 \\
\hline Globalization & & 0.16 & 0.48 & 0.22 & 0.14 \\
\hline \multicolumn{6}{|l|}{ Equity Prices } \\
\hline Full Sample & & & 0.11 & -0.12 & -0.26 \\
\hline Pre-Globalization & & & 0.16 & $-0.26 * * *$ & $-0.39 * * *$ \\
\hline Globalization & & & 0.11 & 0.01 & -0.15 \\
\hline \multicolumn{6}{|l|}{ Credit } \\
\hline Full Sample & & & & 0.20 & 0.08 \\
\hline Pre-Globalization & & & & $0.10 * *$ & $-0.09 * * *$ \\
\hline Globalization & & & & 0.32 & 0.17 \\
\hline \multicolumn{6}{|c|}{ Short-term interest rate } \\
\hline Full Sample & & & & & 0.64 \\
\hline Pre-Globalization & & & & & 0.65 \\
\hline Globalization & & & & & 0.62 \\
\hline
\end{tabular}

Note: The average within country correlation across variables is presented in each cell. The full sample covers the period of 1971:1-2011:3, the pre-globalization period is the sub-period of 1971:1-1984:4, and the globalization period is the subperiod of 1985:1-2011:3.***,**,* denote that the statistics in the pre-globalization period are statistically significantly different from those in the globalization period at 1 percent, 5 percent, and 10 percent levels, respectively. 


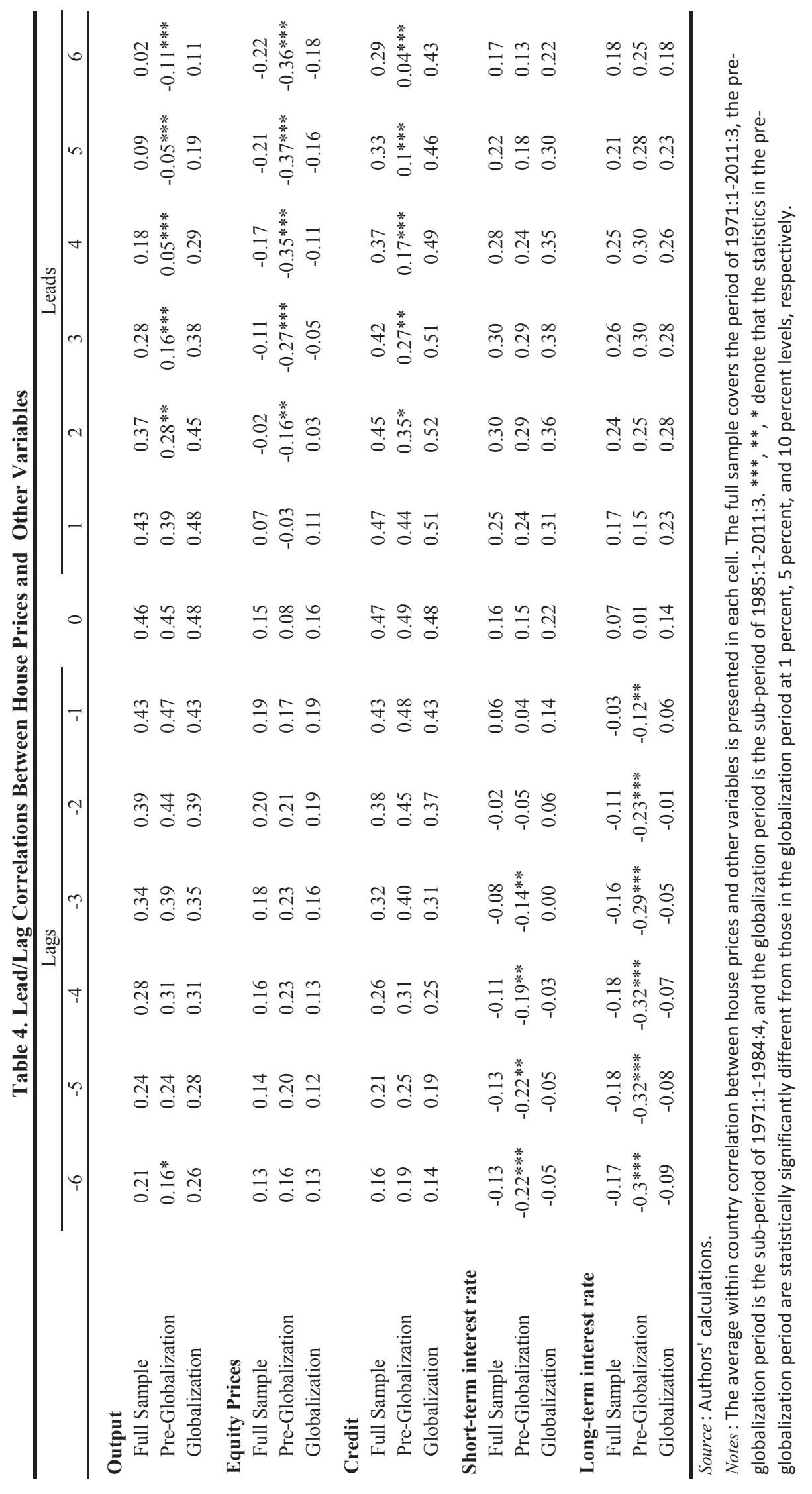


Table 5. Cross-Country Correlations

\begin{tabular}{lccc}
\hline & Full Sample & Pre-Globalization & Globalization \\
\hline Output & 0.43 & $0.32^{* * *}$ & 0.52 \\
House Prices & 0.18 & $0.14^{* * *}$ & 0.23 \\
Equity Prices & 0.56 & $0.43^{* *}$ & 0.64 \\
Credit & 0.26 & $0.24^{* * *}$ & 0.30 \\
Short-term interest rate & 0.33 & $0.29 * * *$ & 0.42 \\
Long-term interest rate & 0.51 & $0.44^{* *}$ & 0.54 \\
\hline
\end{tabular}

Source: Authors' calculations

Notes: The average cross-country correlation is presented in each cell. The full sample covers the period of 1971:12011:3, the pre-globalization period is the sub-period of 1971:1-1984:4, and the globalization period is the sub-period of 1985:1-2011:3.***,**,* denote that the statistics in the pre-globalization period are statistically significantly different from those in the globalization period at 1 percent, 5 percent, and 10 percent levels, respectively.

Table 6. Concordance Across Countries

\begin{tabular}{lccc}
\hline & Full Sample & Pre-Globalization & Globalization \\
\hline Output & 80.17 & 73.49 & 83.22 \\
& $(79.54)$ & $(73.30)$ & $(83.01)$ \\
House Prices & 59.22 & 52.23 & 63.89 \\
& $(58.16)$ & $(50.93)$ & $(61.50)$ \\
Equity Prices & 71.21 & 63.14 & 75.26 \\
& $(69.33)$ & $(63.21)$ & $(72.59)$ \\
Credit & 69.89 & 63.24 & 74.12 \\
& $(69.97)$ & $(59.46)$ & $(74.52)$ \\
\hline
\end{tabular}

Source: Authors' calculations.

Notes: The median of concordance across countries is reported in each cell. Concordance is the fraction of time that two cycles are in the same phase. First the concordance for each country pair is calculated, then the median for each variable over the sample is presented with average values noted in parenthesis.

Table 7. Variance Explained by the Global Factors

\begin{tabular}{lccc}
\hline & Full Sample & Pre-Globalization & Globalization \\
\hline \multirow{2}{*}{ Output } & 0.47 & $0.38^{* * *}$ & 0.56 \\
& $(0.55)$ & $(0.41)$ & $(0.64)$ \\
House Prices & 0.29 & $0.21^{* *}$ & 0.35 \\
& $(0.27)$ & $(0.13)$ & $(0.36)$ \\
Equity Prices & 0.59 & $0.46^{* * *}$ & 0.66 \\
& $(0.59)$ & $(0.47)$ & $(0.69)$ \\
Credit & 0.32 & 0.31 & 0.37 \\
& $(0.33)$ & $(0.27)$ & $(0.41)$ \\
Short-term interest rate & 0.39 & 0.37 & 0.47 \\
& $(0.38)$ & $(0.43)$ & $(0.53)$ \\
Long-term interest rate & 0.55 & 0.51 & 0.59 \\
& $(0.53)$ & $(0.56)$ & $(0.57)$ \\
\hline
\end{tabular}

Source: Authors' calculations

Notes: I he average variance explained by the global tactor is presented in each cell (with median values noted in parenthesis). The full sample covers the period of 1971:1-2011:3, the pre-globalization period is the sub-period of 1971:1-1984:4, and the globalization period is the sub-period of 1985:1-2011:3.***,**,* denote that the statistics in the pre-globalization period are statistically significantly different from those in the globalization period at 1 percent, 5 percent, and 10 percent levels, respectively. 
Table 8. Correlations Among Principal Components of Variables

\begin{tabular}{|c|c|c|c|c|c|}
\hline & Output & House Prices & Equity Prices & Credit & $\begin{array}{l}\text { Short-term } \\
\text { interest rate }\end{array}$ \\
\hline \multicolumn{6}{|l|}{ House Prices } \\
\hline Full Sample & 0.59 & & & & \\
\hline Pre-Globalization & $0.81 * * *$ & & & & \\
\hline Globalization & 0.58 & & & & \\
\hline \multicolumn{6}{|l|}{ Equity Prices } \\
\hline Full Sample & 0.44 & 0.32 & & & \\
\hline Pre-Globalization & $0.33 *$ & $0.13 *$ & & & \\
\hline Globalization & 0.53 & 0.35 & & & \\
\hline \multicolumn{6}{|l|}{ Credit } \\
\hline Full Sample & 0.53 & 0.70 & 0.23 & & \\
\hline Pre-Globalization & $0.86^{* * *}$ & $0.82 * *$ & 0.31 & & \\
\hline Globalization & 0.44 & 0.66 & 0.18 & & \\
\hline \multicolumn{6}{|c|}{ Short-term interest rate } \\
\hline Full Sample & 0.49 & 0.25 & -0.04 & 0.32 & \\
\hline Pre-Globalization & $0.38 *$ & 0.32 & $-0.2 * *$ & $0.17 * *$ & \\
\hline Globalization & 0.57 & 0.32 & 0.11 & 0.50 & \\
\hline \multicolumn{6}{|c|}{ Long-term interest rate } \\
\hline Full Sample & 0.22 & 0.05 & -0.29 & 0.03 & 0.70 \\
\hline Pre-Globalization & $0.05^{*}$ & 0.08 & $-0.39 *$ & $-0.12 * *$ & $0.81 * * *$ \\
\hline Globalization & 0.28 & 0.15 & -0.18 & 0.17 & 0.58 \\
\hline
\end{tabular}

Source: Authors' calculations

Notes: The correlation between pairs of principal components is presented in each cell. The full sample covers the period of 1971:1-2011:3, the pre-globalization period is the sub-period of 1971:1-1984:4, and the globalization period is the sub-period of 1985:1-2011:3. $* * *, * * *$ denote that the statistics in the preglobalization period are statistically significantly different from those in the globalization period at 1 percent, 5 percent, and 10 percent levels, respectively. 
Table 9. Variance Decompositions (Recursive Identification)

\begin{tabular}{|c|c|c|c|c|c|c|}
\hline Period / Shocks & $\begin{array}{c}\text { Forecast } \\
\text { Horizon } \\
\text { (in quarters) }\end{array}$ & $\begin{array}{l}\text { House } \\
\text { Prices }\end{array}$ & Output & $\begin{array}{c}\text { Short-term } \\
\text { Interest Rates }\end{array}$ & Credit & $\begin{array}{l}\text { Equity } \\
\text { Prices }\end{array}$ \\
\hline
\end{tabular}

Full Sample

House Prices

$\begin{array}{cccccc}1 & 91.77 & 3.71 & 0.91 & 3.36 & 0.25 \\ 4 & 74.69 & 2.59 & 14.66 & 7.03 & 1.02 \\ 8 & 57.44 & 3.87 & 27.85 & 7.87 & 2.97 \\ 12 & 52.53 & 5.22 & 28.76 & 8.86 & 4.62\end{array}$

Output

$\begin{array}{cccccc}1 & 8.41 & 84.76 & 1.30 & 0.67 & 4.87 \\ 4 & 26.05 & 52.79 & 4.01 & 5.00 & 12.15 \\ 8 & 28.46 & 37.93 & 14.94 & 7.70 & 10.96 \\ 12 & 27.99 & 35.91 & 15.12 & 9.00 & 11.99\end{array}$

Pre-Globalization

House Prices

4

79.27

9.93

1.33

8.78

0.68

$4 \quad 52.53$

9.75

17.78

16.81

3.14

42.33

9.79

29.96

14.34

3.58

12

34.24

12.16

35.54

13.62

4.44

Output

5.42

75.12

12.17

5.92

1.37

$4 \quad 8.15$

29.78

21.96

25.87

14.24

$\begin{array}{ll}8 & 26.07\end{array}$

15.13

32.96

17.12

8.71

12

24.53

16.29

30.88

17.37

10.94

Globalization

House Prices

$1 \quad 92.55$

92.55
74.61

4.01

1.77

4.75

15.28

1.30

0.36

$4-58.61$
$8-58$

8.99

22.21

3.35

2.00

12

53.81

11.03

21.58

4.98

5.01

6.56

7.01

Output

$\begin{array}{cc}1 & 9.29 \\ 4 & 27.81 \\ 8 & 33.61 \\ 12 & 31.32\end{array}$

82.33

0.79

0.56

7.03

51.10

3.20

3.13

14.77

37.95

10.95

5.39

12.09

36.63

11.73

7.70

12.62

Source: Authors' calculations.

Notes: This table shows the proportion of forecast error variance of factors explained by the respective shocks for different forecast horizons. The model includes the following variables: output, house prices, interest rates, credit, and equity prices, respectively. 
Table 10.A. Variance Decompositions for Credit Shocks (Identification with Sign Restrictions)

\begin{tabular}{lcccccccc}
\hline Shocks & $\begin{array}{c}\text { Forecast } \\
\text { Horizon } \\
\text { (in quarters) }\end{array}$ & $\begin{array}{c}\text { House } \\
\text { Prices }\end{array}$ & Output & $\begin{array}{c}\text { Short-term } \\
\text { Interest } \\
\text { Rates }\end{array}$ & Credit & Inflation & Spread & Default \\
\hline Full Sample & 1 & 8.49 & 9.53 & 8.44 & 13.07 & 5.85 & 2.57 & 17.53 \\
& 4 & 11.07 & 9.77 & 10.64 & 13.67 & 7.50 & 6.28 & 14.33 \\
& 8 & 13.52 & 11.84 & 11.96 & 12.96 & 8.71 & 8.79 & 13.84 \\
Globalization & 12 & 13.60 & 12.20 & 12.76 & 13.60 & 9.66 & 9.47 & 13.84 \\
& 1 & 8.85 & 9.15 & 8.30 & 12.87 & 5.93 & 2.57 & 17.68 \\
& 4 & 11.32 & 9.84 & 10.23 & 13.43 & 7.27 & 6.51 & 14.59 \\
& 12 & 13.60 & 12.06 & 11.46 & 13.31 & 8.44 & 9.16 & 13.98 \\
& 12 & 13.83 & 12.73 & 12.30 & 13.83 & 9.28 & 10.01 & 14.18 \\
\hline
\end{tabular}

Note: This table shows the proportion of forecast error variance of factors explained by credit shocks for different forecast horizons. Variance decompositions for the pre-globalization period are not available because of the lack of data series of spreads and defaults.

Table 10.B. Variance Decompositions for Monetary Policy Shocks (Identification with Sign Restrictions)

\begin{tabular}{|c|c|c|c|c|c|c|c|c|}
\hline \multirow[b]{2}{*}{ Shocks } & \multirow{2}{*}{$\begin{array}{c}\text { Forecast } \\
\text { Horizon } \\
\text { (in quarters) }\end{array}$} & \multirow[b]{2}{*}{$\begin{array}{l}\text { House } \\
\text { Prices }\end{array}$} & \multicolumn{3}{|c|}{ Short-term } & \multicolumn{3}{|c|}{ Long- } \\
\hline & & & Output & $\begin{array}{c}\text { Interest } \\
\text { Rates }\end{array}$ & Credit & Inflation & $\begin{array}{c}\text { term } \\
\text { Interest }\end{array}$ & Reserves \\
\hline \multirow[t]{4}{*}{ Full Sample } & 1 & 8.65 & 11.64 & 12.64 & 6.64 & 3.25 & 10.87 & 18.35 \\
\hline & 4 & 10.89 & 12.66 & 11.33 & 8.43 & 5.46 & 11.19 & 16.39 \\
\hline & 8 & 12.54 & 14.32 & 11.27 & 11.31 & 6.73 & 10.47 & 15.55 \\
\hline & 12 & 12.48 & 14.01 & 11.28 & 11.86 & 7.77 & 9.84 & 15.42 \\
\hline \multirow[t]{4}{*}{ Pre-Globalization } & 1 & 10.27 & 10.72 & 8.93 & 11.01 & 8.28 & 11.92 & 16.35 \\
\hline & 4 & 13.00 & 13.06 & 11.93 & 13.50 & 10.11 & 12.16 & 15.52 \\
\hline & 8 & 13.29 & 12.82 & 13.11 & 12.70 & 12.71 & 12.76 & 15.13 \\
\hline & 12 & 13.64 & 13.30 & 13.95 & 13.46 & 13.45 & 13.70 & 14.78 \\
\hline \multirow[t]{4}{*}{ Globalization } & 1 & 9.20 & 8.70 & 21.06 & 7.42 & 4.53 & 11.36 & 13.46 \\
\hline & 4 & 13.86 & 9.99 & 17.36 & 9.42 & 7.15 & 12.35 & 13.27 \\
\hline & 8 & 14.21 & 11.88 & 15.68 & 13.37 & 8.79 & 13.12 & 13.32 \\
\hline & 12 & 14.27 & 12.59 & 15.14 & 13.95 & 9.68 & 13.32 & 13.34 \\
\hline
\end{tabular}

Note: This table shows the proportion of forecast error variance of factors explained by monetary policy shocks for different forecast horizons.

Table 10.C. Variance Decompositions for Productivity Shocks (Identification with Sign Restrictions)

\begin{tabular}{lcccccccc}
\hline Shocks & $\begin{array}{c}\text { Forecast } \\
\text { Horizon } \\
\text { (in quarters) }\end{array}$ & $\begin{array}{c}\text { House } \\
\text { Prices }\end{array}$ & Output & $\begin{array}{c}\text { Short-term } \\
\text { Interest } \\
\text { Rates }\end{array}$ & Credit & Inflation & $\begin{array}{c}\text { Long- } \\
\text { term } \\
\text { Interest }\end{array}$ & Reserves \\
\hline Full Sample & 1 & 7.30 & 18.18 & 7.32 & 7.78 & 14.25 & 10.73 & 7.39 \\
& 4 & 7.77 & 16.34 & 10.47 & 9.83 & 14.11 & 13.17 & 9.24 \\
& 8 & 10.56 & 15.08 & 12.61 & 12.48 & 13.98 & 13.88 & 10.38 \\
Pre-Globalization & 12 & 11.77 & 15.05 & 13.22 & 13.41 & 13.97 & 13.87 & 10.77 \\
& 1 & 10.40 & 14.91 & 10.84 & 11.13 & 10.20 & 11.81 & 8.50 \\
& 4 & 12.71 & 15.36 & 12.24 & 13.72 & 11.92 & 13.08 & 10.39 \\
Globalization & 12 & 13.72 & 14.84 & 12.81 & 13.86 & 12.91 & 13.03 & 11.48 \\
& 12 & 13.67 & 14.30 & 13.16 & 13.96 & 13.48 & 13.29 & 11.79 \\
& 4 & 7.66 & 19.99 & 9.56 & 7.93 & 10.82 & 10.38 & 4.45 \\
& 8 & 12.42 & 17.61 & 12.63 & 10.97 & 11.01 & 12.16 & 8.81 \\
& 12 & 12.96 & 15.79 & 12.81 & 13.63 & 11.30 & 12.39 & 10.17 \\
& 12.73 & 13.77 & 11.78 & 12.27 & 11.25 \\
\hline
\end{tabular}

Note: This table shows the proportion of forecast error variance of factors explained by productivity shocks for different forecast horizons. 
Table 11.A. Variance Decompositions for Uncertainty Shocks (Recursive Identification, 18 Countries)

\begin{tabular}{lcccc}
\hline & $\begin{array}{c}\text { Forecast Horizon } \\
\text { (in quarters) }\end{array}$ & House Prices & Output & Equity Prices \\
\cline { 2 - 5 } Full Sample & 1 & 1.57 & 5.74 & 2.20 \\
& 4 & 2.04 & 10.63 & 7.75 \\
& 8 & 5.05 & 9.89 & 7.93 \\
Pre-Globalization & 12 & 6.42 & 10.12 & 7.86 \\
& 1 & 6.36 & 18.26 & 2.64 \\
& 4 & 15.72 & 15.50 & 14.79 \\
Globalization & 14.12 & 12.48 & 16.90 \\
& 12 & 14.24 & 13.86 & 19.68 \\
& 1 & 2.39 & 4.80 & 1.88 \\
& 4 & 7.99 & 9.50 & 5.88 \\
& 12 & 15.10 & 9.14 & 7.28 \\
& 12 & 15.87 & 11.01 & 7.92
\end{tabular}

Note: This table shows the proportion of forecast error variance of factors explained by the uncertainty shocks for different forecast horizons.

Table 11.B Variance Decompositions for Uncertainty Shocks (Recursive Identification, G7 Countries)

\begin{tabular}{lcccc}
\hline & $\begin{array}{c}\text { Forecast Horizon } \\
\text { (in quarters) }\end{array}$ & House Prices & Output & Equity Prices \\
\cline { 2 - 4 } Full Sample & 1 & 1.20 & 4.09 & 1.65 \\
& 4 & 5.18 & 5.13 & 3.95 \\
& 8 & 9.49 & 7.53 & 6.47 \\
Pre-Globalization & 12 & 10.72 & 8.39 & 6.75 \\
& 1 & 6.03 & 9.88 & 2.73 \\
& 4 & 9.03 & 11.65 & 8.98 \\
Globalization & 11.63 & 12.07 & 11.29 \\
& 12 & 12.79 & 13.97 & 12.48 \\
& 1 & 5.56 & 5.68 & 1.80 \\
& 4 & 20.74 & 4.75 & 4.97 \\
& 8 & 29.07 & 15.04 & 8.71 \\
& 12 & 29.10 & 15.22 & 9.17 \\
\hline
\end{tabular}

Note: This table shows the proportion of forecast error variance of factors explained by the uncertainty shocks for different forecast horizons. 
Figure 1. Coincidence of House Price Downturns and Recessions

(in percent)

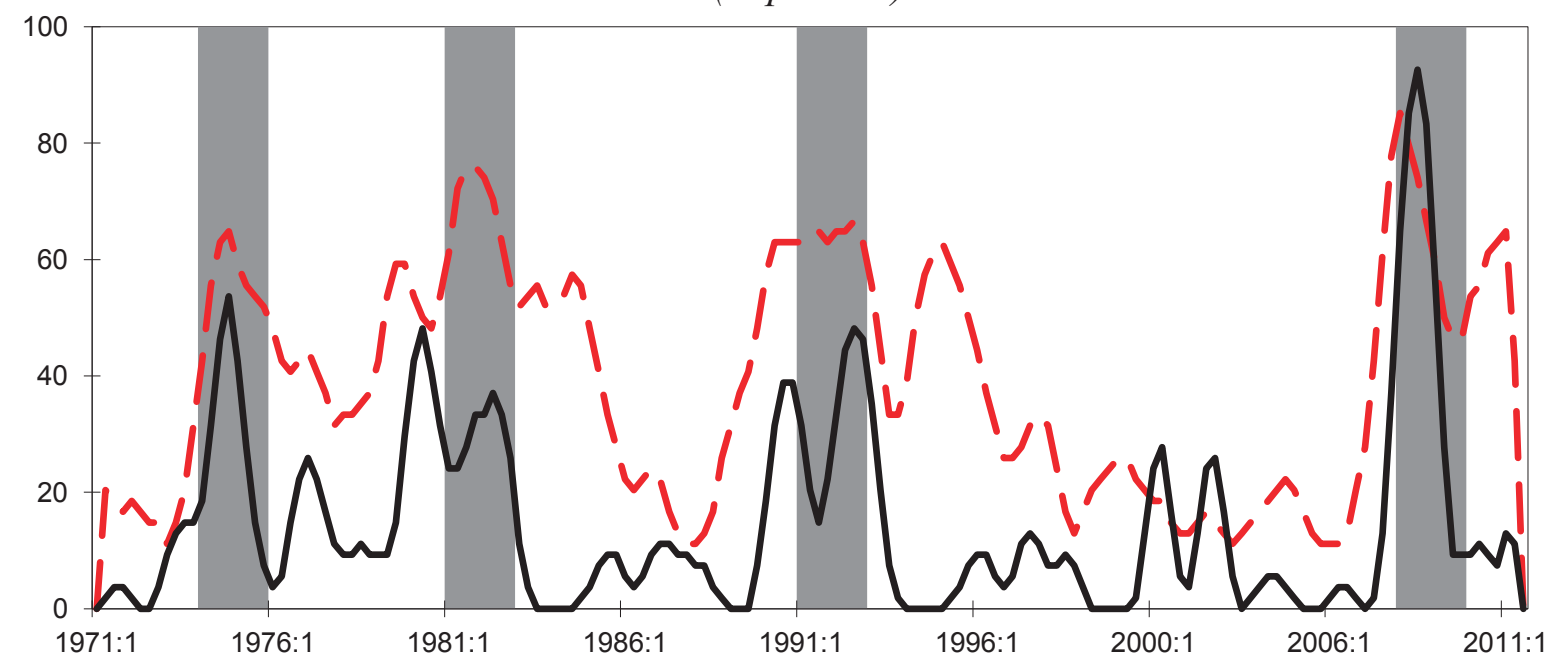

Notes: Black line shows the share of countries experiencing recessions, red line shows the share of countries experiencing house price downturns, and the gray bars represent the years of global recessions (1975, 1982, 1991, and 2009) and the preceding (1974, 1981, 2008) and succeeding (1992) periods.

Recessions and house price downturns are identified following Claessens, Kose, and Terrones (2012). At the beginning and end of samples only complete episodes are included. The dates of global recessions are from Kose, Loungani, and Terrones (2009). 
Figure 2. Global Factors of Financial Variables and Output (in percent, growth rates)

House Prices
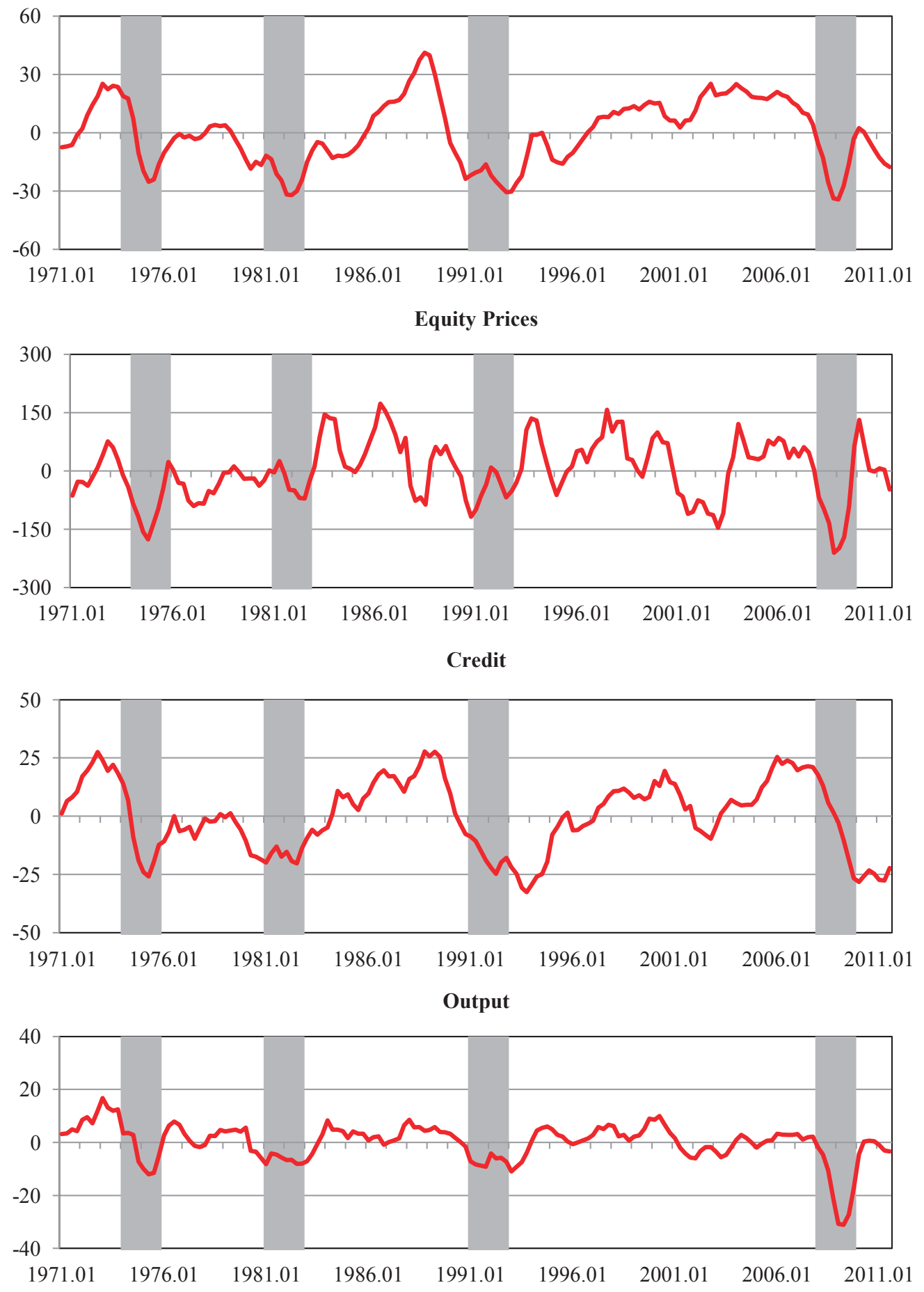

Notes: The graphs show the global factors estimated using the first principal components of the growth rates of respective variables. The gray bars represent the global recessions and preceding and succeeding periods. See Figure 1 for additional information. 
Figure 3. Distributions of Cross-Country Correlations

(in percent)

House Prices

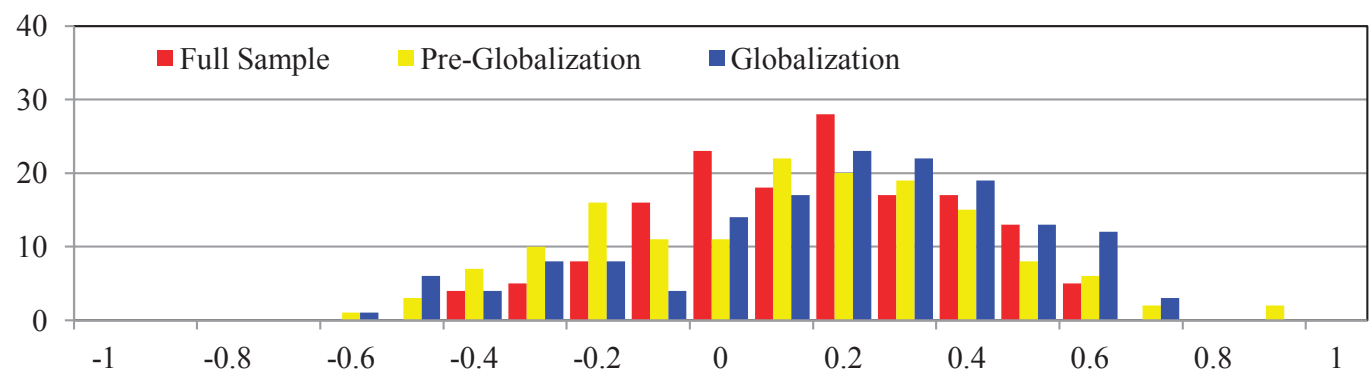

Equity Prices

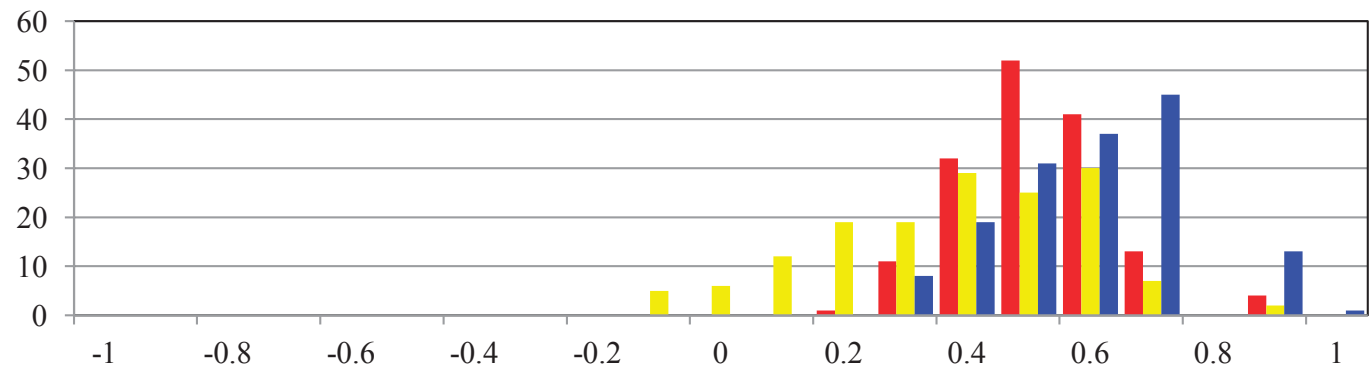

Credit

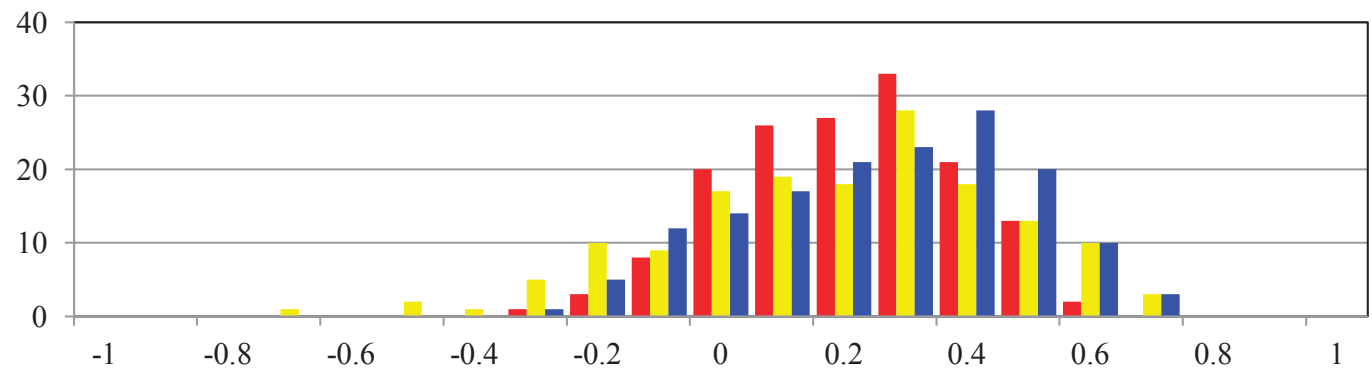

Output

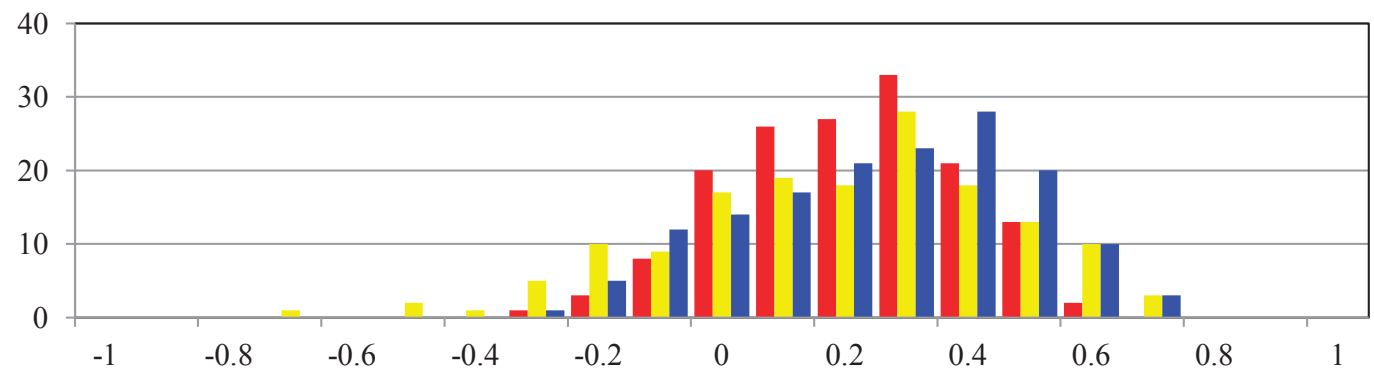

Note: Each panel presents the histograms of the cross-country correlations of the respective variable.

Kolmogorov-Smirnoff tests indicate that there are statistically significant differences across distributions in the pre-globalization and globalization periods. 
Figure 4.A. Impulse Responses of House Prices to Different Shocks (18 Countries)
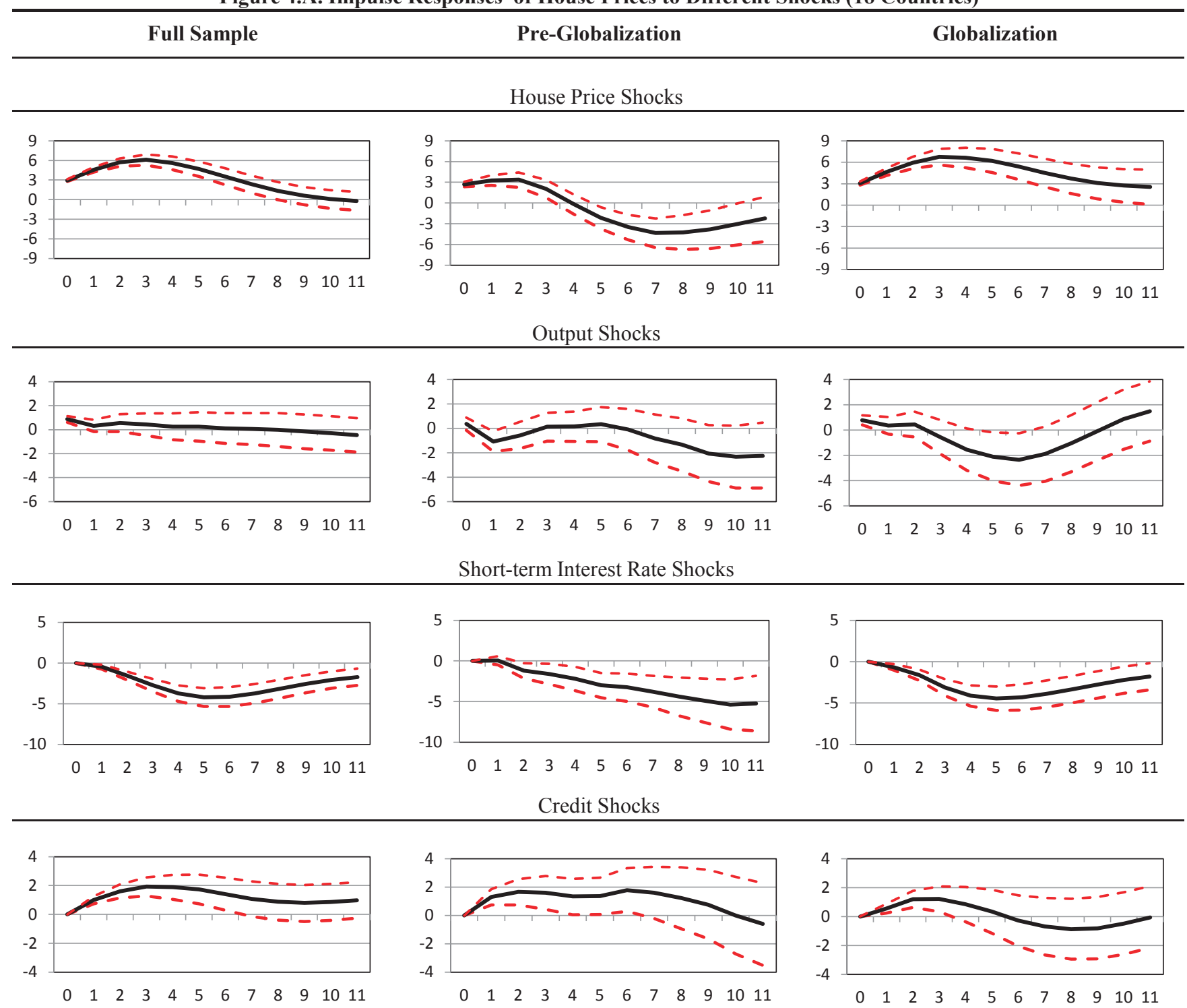

Equity Price Shocks
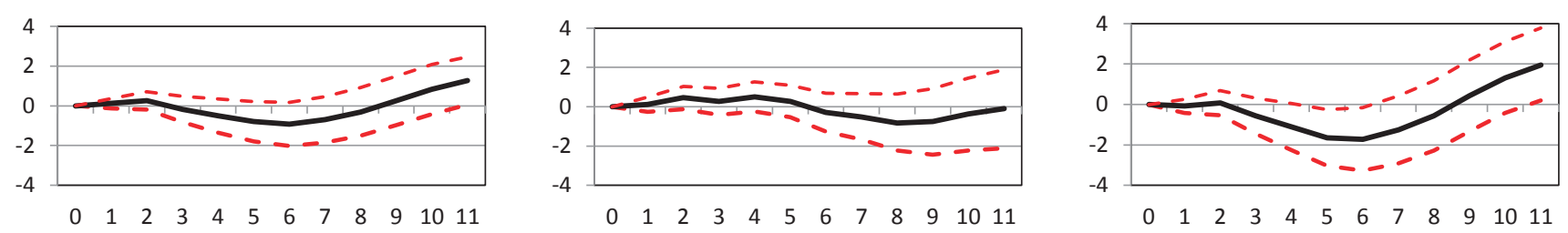

Note: The graphs show the impulse responses of house prices to respective shocks. The solid line represents the median estimate and the dotted lines denote the 16 percent and 84 percent error bands. 
Figure 4.B. Impulse Responses of House Prices to Interest Rate Shocks
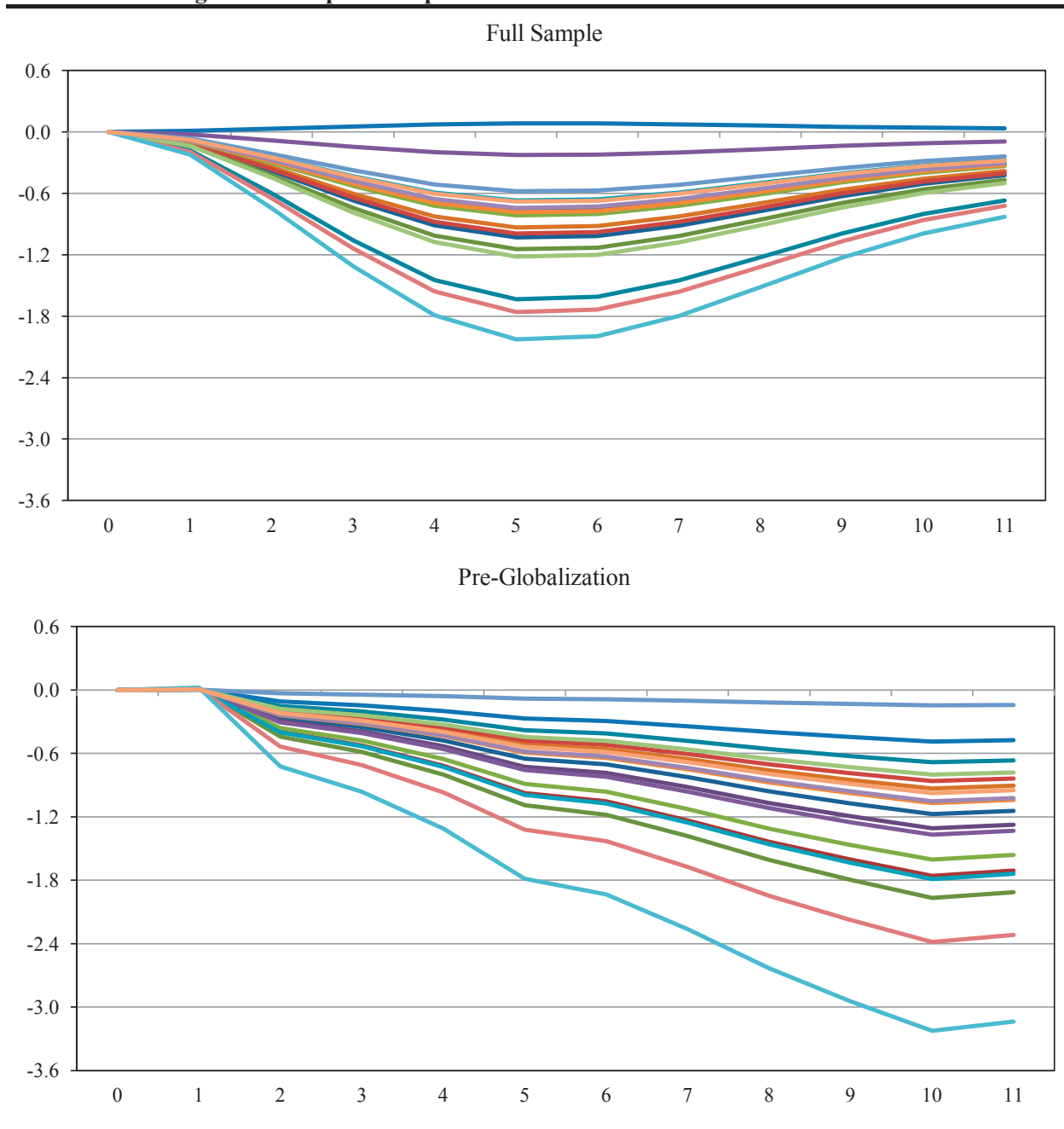

Globalization

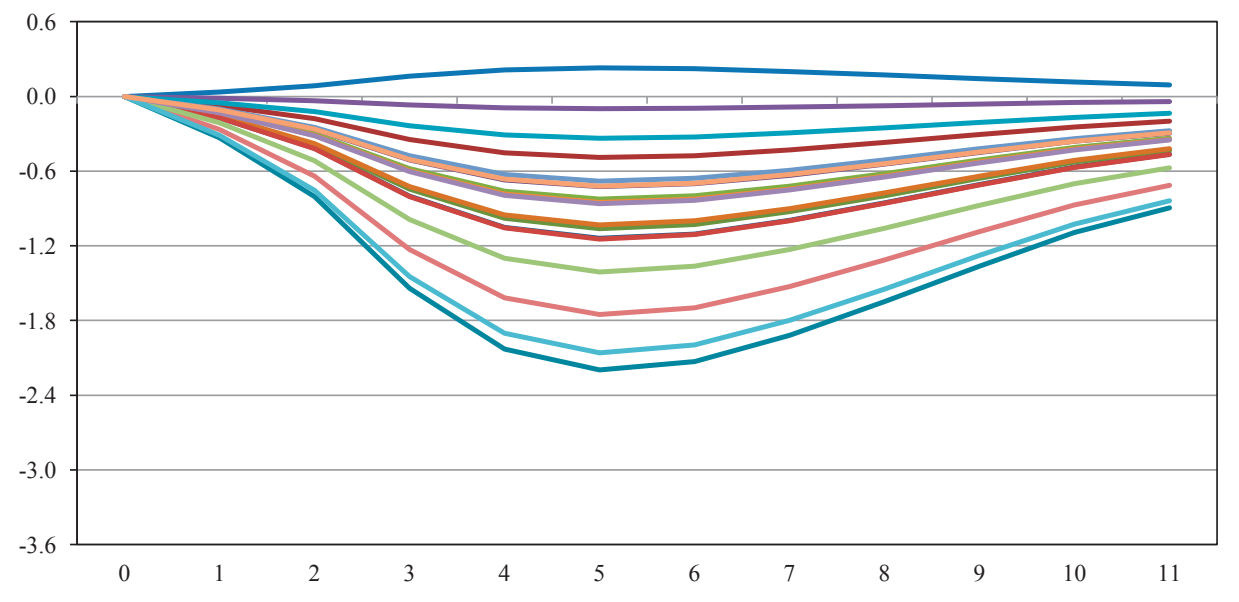

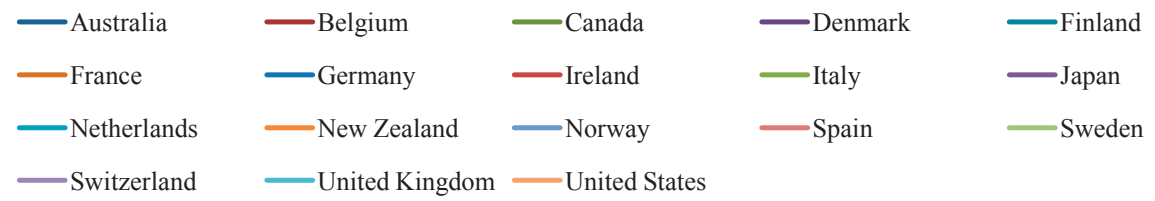

Note: The graphs show the median impulse response of house prices to shocks to short-term interest rates for each country in the sample. 
Figure 5.A. Impulse Responses to Monetary Policy Shocks (18 Countries)
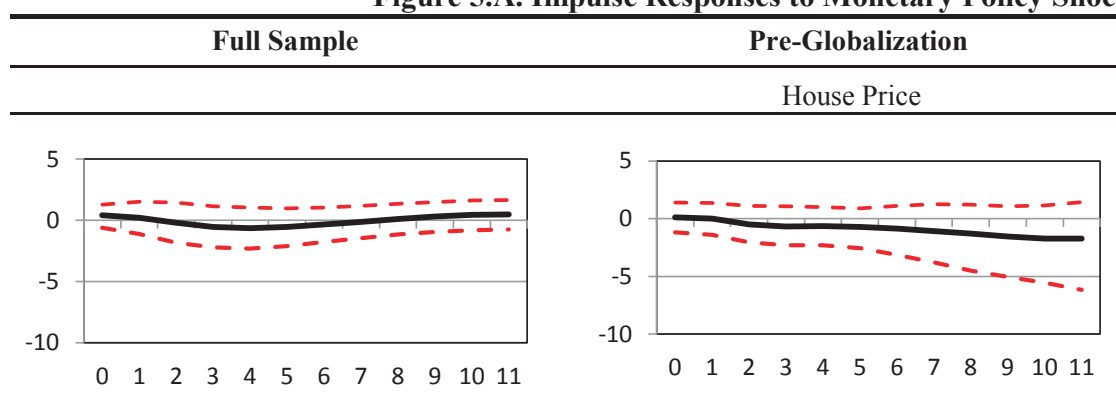

Output
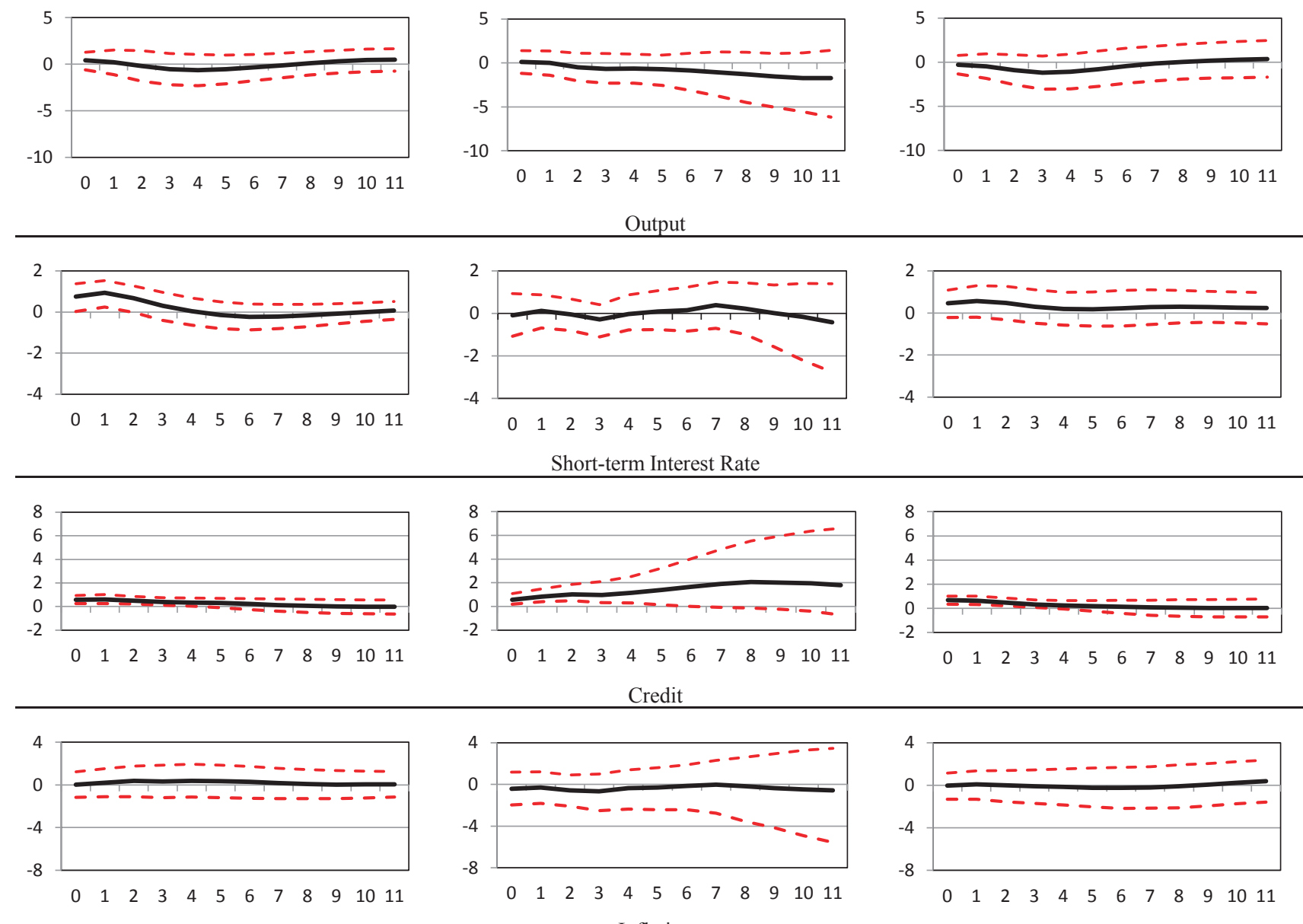

Inflation
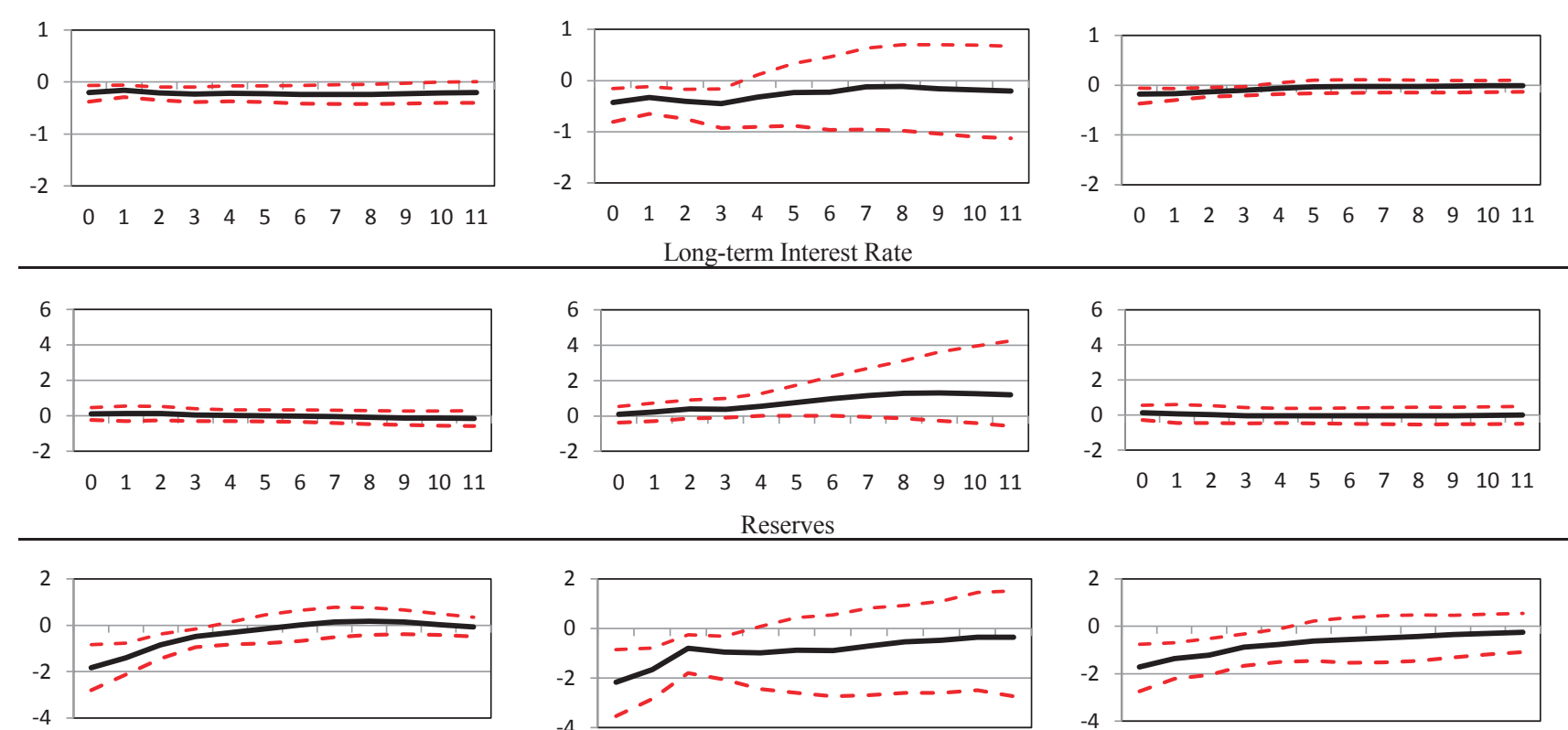

$\begin{array}{llllllllllll}0 & 1 & 2 & 3 & 4 & 5 & 6 & 7 & 8 & 9 & 10 & 11\end{array}$
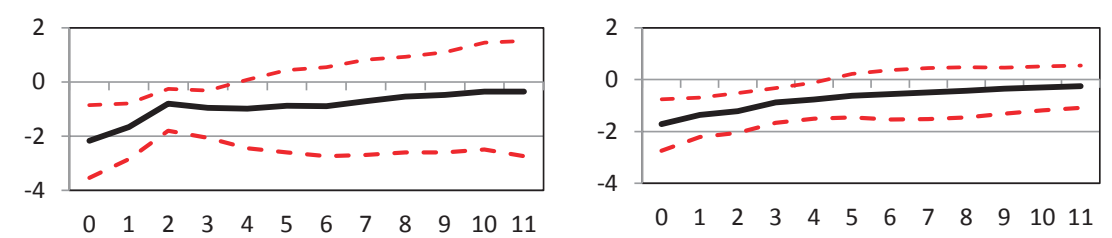

Note: The graphs show the impulse responses of respective variables to money shocks. The solid line represents the median estimate and the dotted lines denote the 16 percent and 84 percent error bands. 
Figure 5.B. Impulse Responses to Credit Shocks (18 Countries)

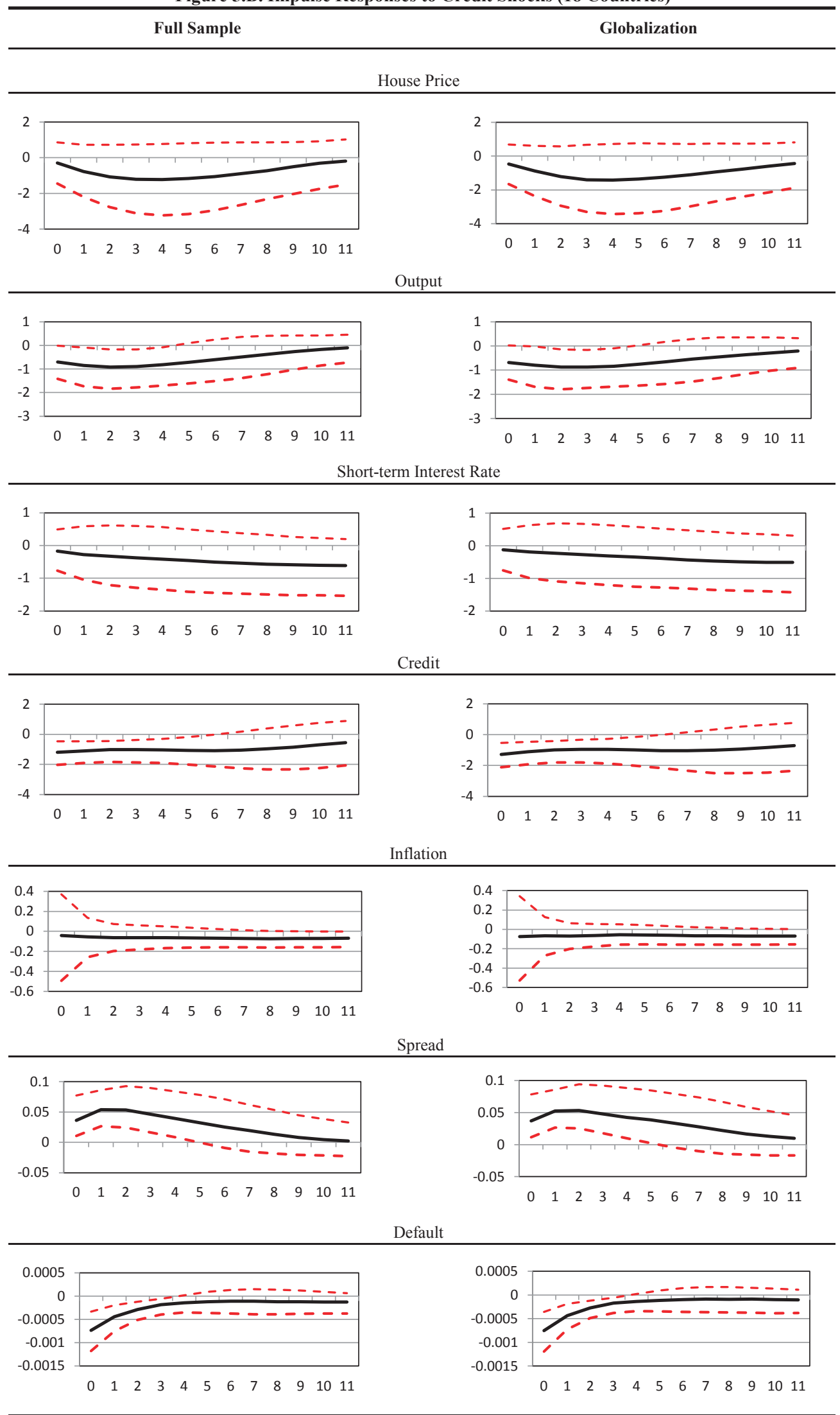

Notes: The graphs show the impulse responses of respective variables to credit shocks. The solid line represents the median estimate and the dotted lines denote the 16 percent and 84 percent error bands. Figures for the pre-globalization period are not available because of the lack of data series of spreads and defaults. 
Figure 5.C. Impulse Responses to Productivity Shocks (18 Countries)

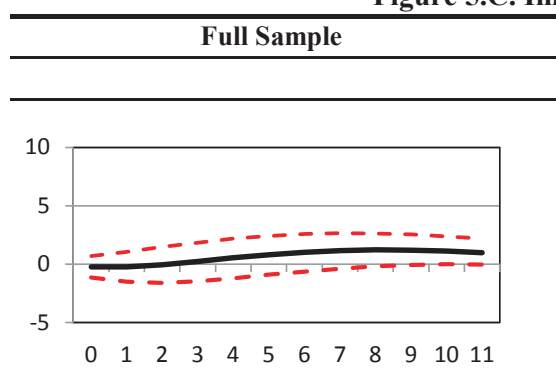

Pre-Globalization

Globalization

House Price
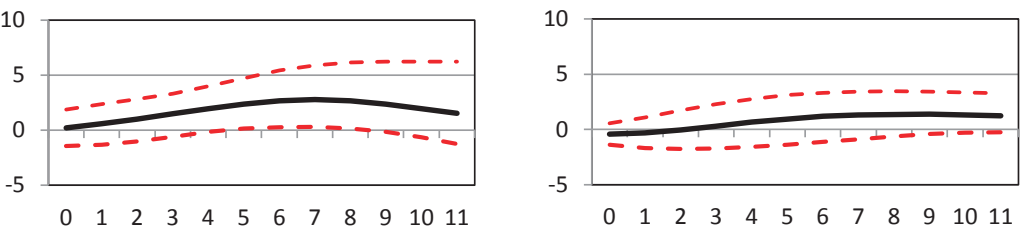

Output
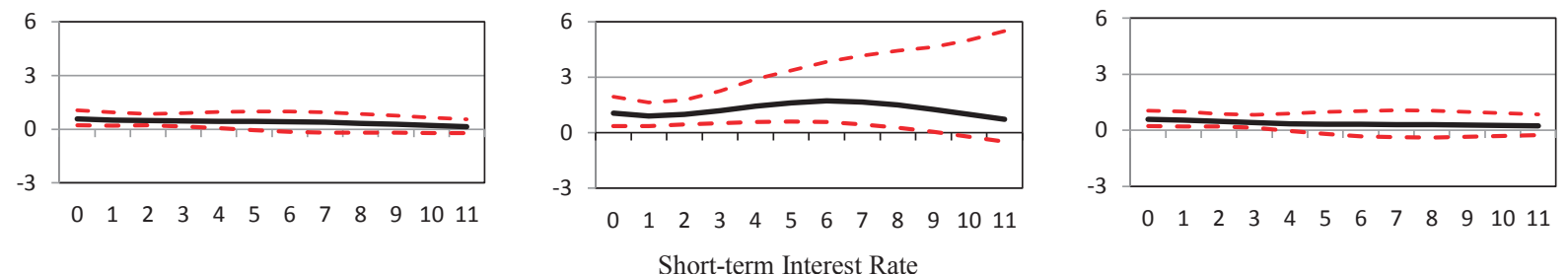

Short-term Interest Rate
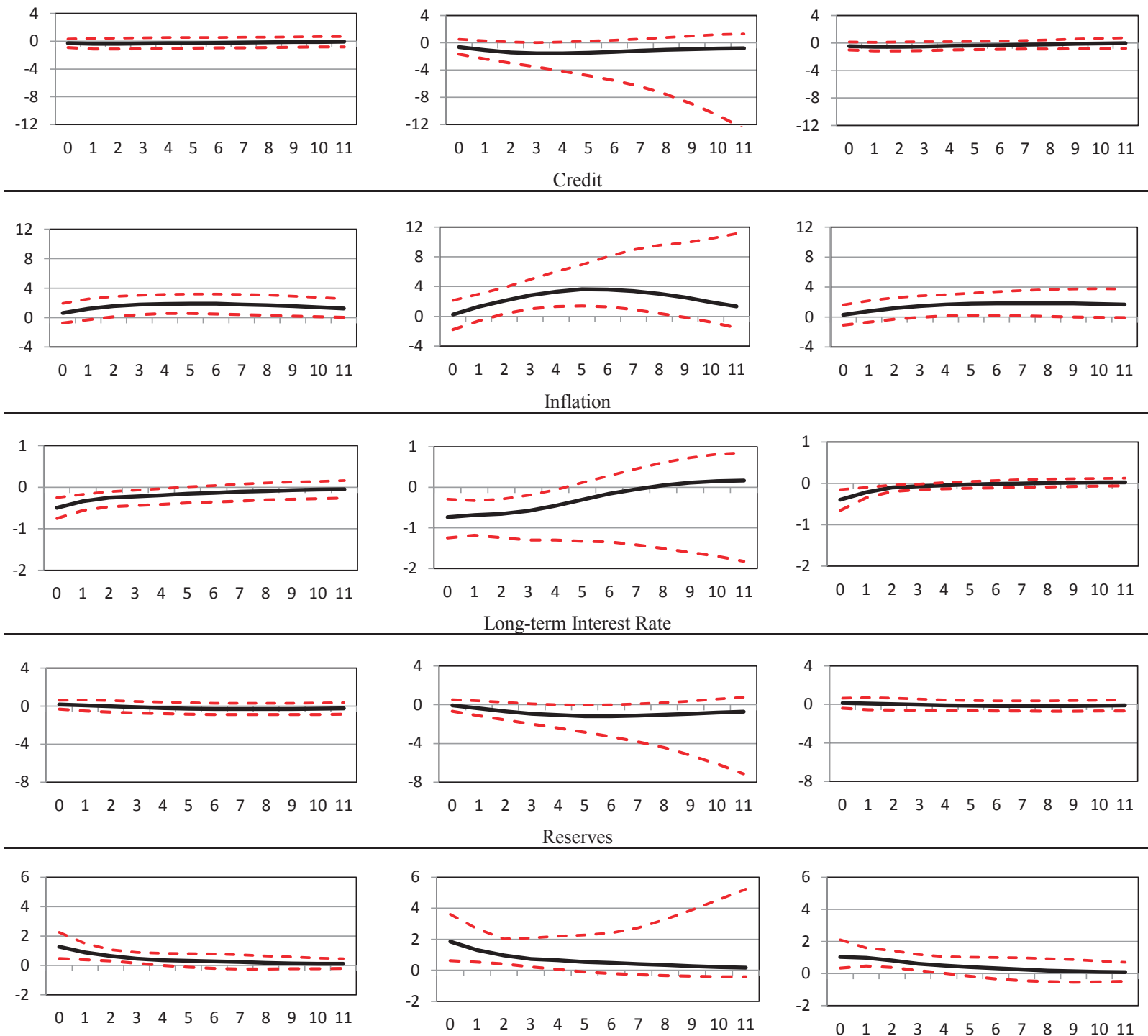

Note: The graphs show the impulse responses of respective variables to productivity shocks. The solid line represents the median estimate and the dotted lines denote the 16 percent and 84 percent error bands. 
Figure 6.A. Impulse Responses to Uncertainty Shocks (18 Countries)

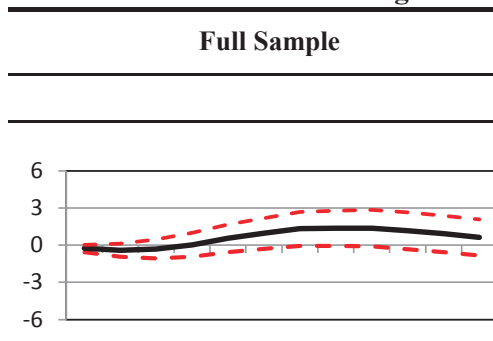

$\begin{array}{lllllllllllll}0 & 1 & 2 & 3 & 4 & 5 & 6 & 7 & 8 & 9 & 10 & 11\end{array}$
Pre-Globalization

House Prices

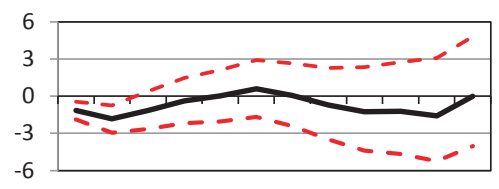

$\begin{array}{llllllllllll}0 & 1 & 2 & 3 & 4 & 5 & 6 & 7 & 8 & 9 & 10 & 11\end{array}$

Output

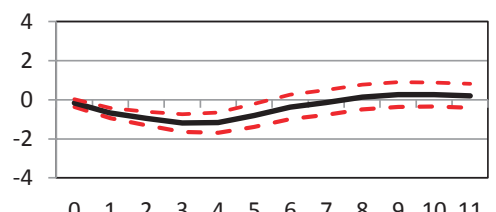

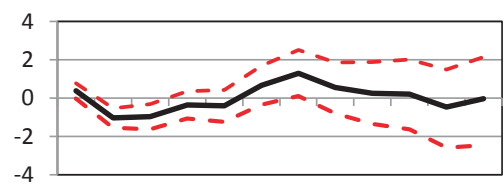

$\begin{array}{lllllllllllll}0 & 1 & 2 & 3 & 4 & 5 & 6 & 7 & 8 & 9 & 10 & 11\end{array}$

Equity Prices

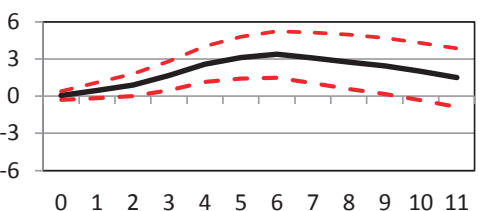

$\begin{array}{llllllllllll}0 & 1 & 2 & 3 & 4 & 5 & 6 & 7 & 8 & 9 & 10 & 11\end{array}$
Globalization

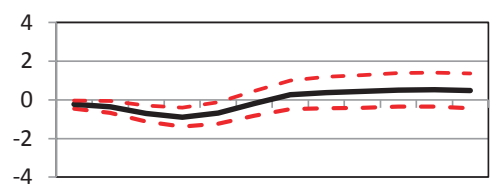

$\begin{array}{llllllllllll}0 & 1 & 2 & 3 & 4 & 5 & 6 & 7 & 8 & 9 & 10 & 11\end{array}$
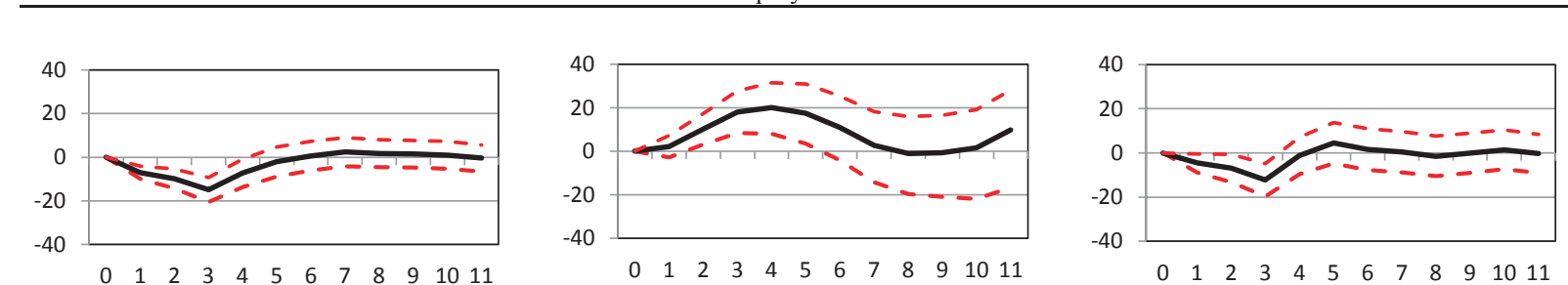

Note: The graphs show the impulse responses of respective variables to uncertainty shocks. The solid line represents the median estimate and the dotted lines denote the 16 percent and 84 percent error bands.

Figure 6.B. Impulse Responses to Uncertainty Shocks (G7 Countries)

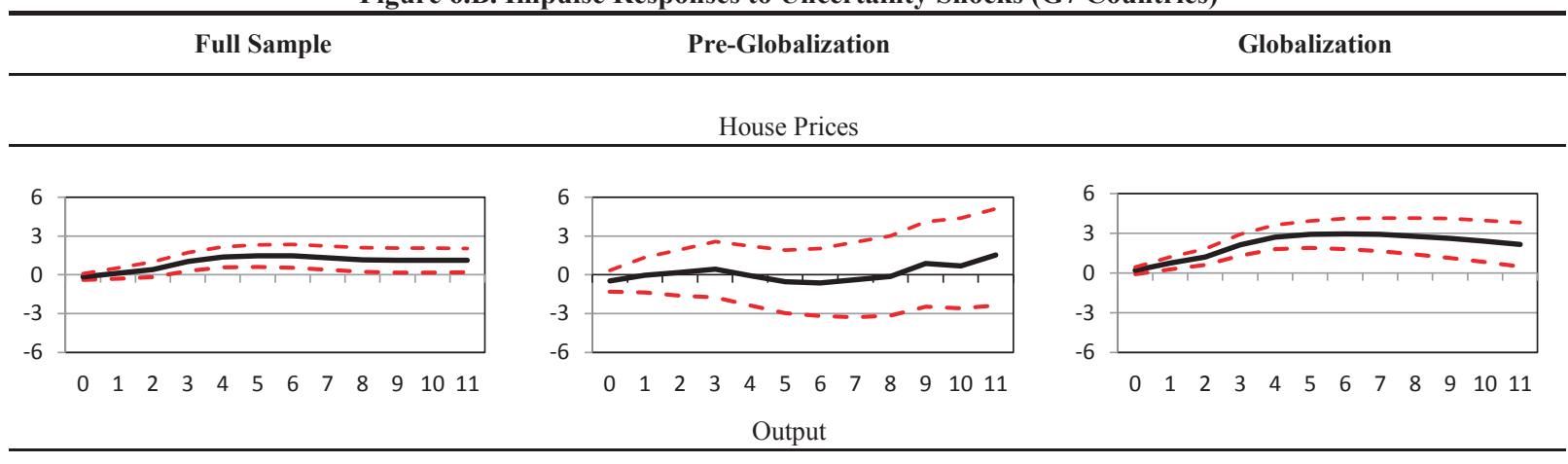

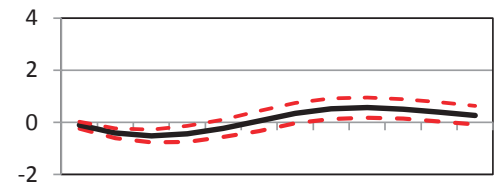

$\begin{array}{lllllllllllll}0 & 1 & 2 & 3 & 4 & 5 & 6 & 7 & 8 & 9 & 10 & 11\end{array}$

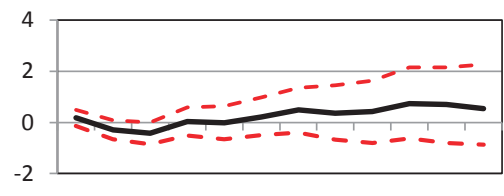

$\begin{array}{lllllllllllll}0 & 1 & 2 & 3 & 4 & 5 & 6 & 7 & 8 & 9 & 10 & 11\end{array}$

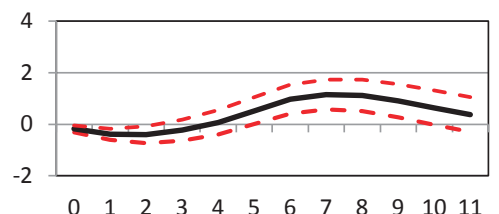

$\begin{array}{lllllllllllll}0 & 1 & 2 & 3 & 4 & 5 & 6 & 7 & 8 & 9 & 10 & 11\end{array}$

Equity Prices
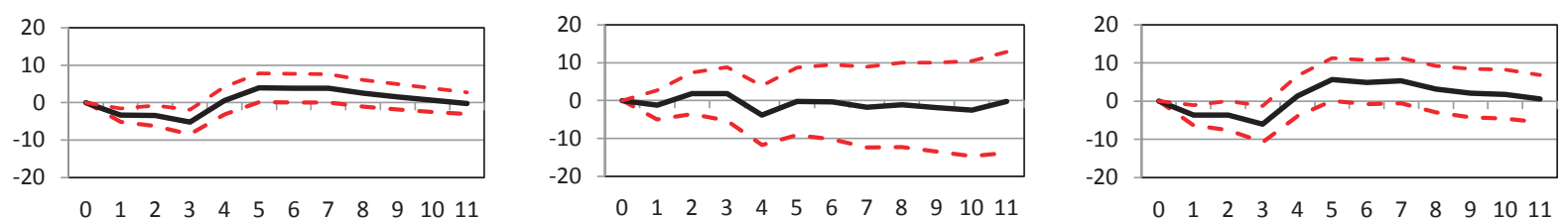

Note: The graphs show the impulse responses of respective variables to uncertainty shocks. The solid line represents the median estimate and the dotted lines denote the 16 percent and 84 percent error bands. 